\title{
Afet İçerikli Haberlerin Afetlere Karşı Toplumsal Kapasite Geliştirmeye Etkisi
}

\author{
Serhat Yılmaz ${ }^{1, *}$ \\ ${ }^{1}$ Istanbul Aydın Üniversitesi, Afet Eğitim Uygulama ve Araştırma Merkezi, 34295, İstanbul.

\section{Özet}

Afetlere karşı yürütülen hazırlık çalışmalarının en önemli hedeflerinden birisini toplumsal yaşamın devamlılı̆̆ını sağlamak oluşturmaktadır. Bu hedefe ulaşabilmede ise afetlere karşs bireysel risk azaltma faaliyetlerinin yürütülmesi hayati önem taşımaktadır. Ancak afet riski altındaki bir toplumun geneline ulaşarak bu farkındalığı oluşturmak zaman ve maliyet açısından yüksek değerlerle gerçekleşebilmektedir. Günlük yaşam içerisinde bilgi ihtiyacının karşılanması amacılla toplumun genelinde yaygın olarak kullanılan özellikle gazete ve televizyon gibi kitle iletişim araçları bu yüksek maliyetleri azaltabilecek önemli avantajlar sunmaktadır. Bu çalışma kapsamında kitle iletişim araçlarının sağladığı bu avantajların afetlere yönelik toplumsal kapasite geliştirme bağlamında ne kadar etkin kullanıldığı incelenmiştir. Bu bağlamda, Türkiye genelinde en çok okunan ilk üç gazete ve en yüksek izlenme oranına sahip ilk üc ana haber programının 21 Temmuz 2017 tarihli Bodrum Depremi özelinde yayımladıkları haberlerin içerik analizleri çerçeveleme kuramı kullanılarak incelenmekte ve afetlere karşı toplumsal kapasite geliştirmeye etkileri sorgulanmaktadır. Çalışmada kitle iletişim araçlarının afetlerle ilgili içeriklerde haberi büyük ilgi çeken (sansasyonel) boyutuyla ele aldı ̆̆l, bireysel hazırliğa yönelik bir farkındalık oluşturmada kitle iletiş̧im araçlarının sunduğu avantajlardan yeteri kadar yararlanılmadığı sonuçlarına ulaşılmaktadır.

\section{$\underline{\text { Anahtar Sözcükler }}$}

Kapasite Geliştirme, Kitle İletişimi, Afet Haberleri, Afet Farkındalığı

\section{The Impact of the Disaster News on Social Capacity Building Against Disasters}

\begin{abstract}
Providing that, the continuum of social life is one of the most important aims of the preparedness against disasters, carrying individual risk reduction activities against disasters is vital for achieving this goal. However, increasing the awareness of a society under disaster risk can be realized with high costs and time. Mass media tools, especially newspapers and television which are widely used in daily life for accessing the information needed, are offering an advantage in order to decrease these high costs and are much faster. Within the scope of this study, the effectiveness of these mass media tools in the context of social capacity building on disasters has been examined. For this purpose, the contents of the Bodrum Earthquake's (occurred on July 27 th 2017) news which were published in the first three most widely read newspapers in Turkey, and were broadcasted on the first three rated news programs, were analyzed by framing theory. After these analyses, the effects on the social capacity building against disaster are being questioned. As a result of the study, it has been revealed that the disaster news are generally being addressed with sensational perspective, and the advantages being offered by the mass media tools are not effectively utilized for creating awareness on individual preparedness activities.
\end{abstract}

$\underline{\text { Keywords }}$

Capacity Building, Mass Communication, Disaster News, Disaster Awareness

\section{Giriş}

Göçebe hayat tarzında avcı - toplayıcı olarak yaşamlarını devam ettirirken tarım toplumuna oranla daha az doğadan etkilenen insanlığın yerleşik yaşama geçişi, doğa ile olan ilişkisini de değiştirmektedir. Oluşturdukları kalıcı yerleşim alanları ve tarım arazilerinin doğadan gelebilecek sel ve su baskınları gibi tehlikelere karşı korunması gerekliliği, insanların doğaya karşı kapsamlı önlemler alma arayışının başlangıcı olarak kabul edilmektedir. Bu nedenle yerleşik yaşama geçiş insanlığın toplumsal evriminde önemli bir değişim olarak görülmektedir. Toplumsal gelişimde diğer önemli bir değişim ise sanayi devrimi ile gerçekleşmektedir. Yaklaşık 250 y1l önce başlayan bu devrim ile birlikte düzenli olarak artan kentsel nüfus 21. yüzyılın ilk on yılına gelindiğinde dünya nüfusunun yarısından fazlasının kentlerde toplanmasına neden olmaktadır (Worldwatch Enstitüsü 2016). Sanayi Devriminden sonra yoğunluğu artan ve insanlık tarihi ile kıyasladığımızda kısa bir zaman diliminde küresel bir eğilim olarak gerçekleșen kentleşme yönelimleri beraberinde birçok sorunun da ortaya çıkmasına neden olmaktadır. 
Çalışma kapsamında değinilen bu sorunların önemli bir bölümünün temelinde ise, nüfusun ve ekonomik değerlerin kısıtlı bir bölge olan kentlerde yoğunlaşması ve dünyanın doğal devinimi sonucu oluşan jeolojik, meteorolojik kaynaklı hareketliliğin ve insani etkilerin yarattığı afet riskleri yer almaktadır. Bu risklerin kentler üzerinde neden olabileceği etkileri anlayabilmek için afetin tanımına bakmak gerekmektedir. Birleşmiş Milletlere göre afet "İnsanlar için fiziksel, ekonomik ve sosyal kayıplara neden olan, normal yaşamı durdurarak veya kesintiye uğratarak toplumları etkileyen ve yerel imkânlar ile baş edilemeyen her türlü doğal, teknolojik veya insan kaynaklı tüm olaylar" olarak tanımlanmaktadır (Kadığlu 2008). Afetlere yönelik farklı kaynaklarda benzer nitelikte birçok tanımlama yapılmakta ve afetin neden değil sonuç olduğu ve etkisi itibariyle toplumsal yaşamın devamlılığına büyük zararlar verebilecek sonuçlar doğuracağı vurgulanmaktadir.

Geçmişte yaşanan afetler incelendiği zaman afet riski altında olan bir bölgede yaşayan nüfus yoğunluğu ne kadar az ise afetin etkisinin de o kadar sınırlı olduğu görülmektedir. Günümüzde ise milyonların bir arada yaşadığı devasa kentlerdeki nüfus yoğunluğu, ekonomik birikimin fazlalığı, kentleşmenin getirdiği teknolojik kazalar gibi yeni risk kaynakları olası afetlerde çok daha büyük kayıpların oluşmasına zemin hazırlamaktadır. Bir de bu duruma yaygın olarak tüketilen fosil yakıtlar, bilinçsiz arazi kullanımı, ormansızlaştırmalar, atmosfere salınan sera gazları, bilinçsizce üretilen atıklar ve diğer beşeri kaynaklı çevresel tahribatların eklenmesi yeni afet türlerini oluşturacak risk havuzları yaratmaktadır. Tarihi boyunca çeşitli derecelerde afetlerden etkilenen insanlık, geçmiş deneyimlerinden edindiği dersler doğrultusunda afetlere karşı nasıl korunabileceğinin cevaplarını ararken tarım toplumunun basit korunma yöntemlerinden devasa kentlerin karmaşık yapılarını korumaya doğru gelişim göstermektedir. Bugün gelinen noktada ise küreselleşen dünyanın da etkisi ile bir kenti afetten korumanın bu kent ile ekonomik, sosyal ve kültürel bağları olan diğer kentlerin görebileceği zararları da azaltacağının fark edilmesi, uluslararası önlemleri gündeme getirmektedir (Worldwatch Enstitüsü 2016).

Uluslararası düzeyde alınabilecek önlemler ise 'Birleşmiş Milletler İklim Değişikliği Çevre Sözleşmesi', 'Kyoto Protokolü', 'Hygo Çerçeve Eylem Planı', 'Sendai Afet Risk Azaltma Çerçevesi' ve 'BM İklim Değişikliği Taraflar Konferansı-(COP-21)' gibi işbirlikleri ile uygulanmaya çalışılmaktadır. Yürütülen tüm bu çalışmaların nihai hedefinde ise sürdürülebilir bir çevre içerisinde doğal yaşama zarar vermeden toplumsal gelişimin devamlılı̆̆ının sağlanması yer almaktadır. Bu hedefe ulaşabilmek için bireysel ve kurumsal farkındalığın artırılması ve önlem alma kültürünün yaygınlaştırılması kilit bir öneme sahiptir. Bu öneme rağmen gerek küresel gerekse yerel ölçekte uygulanmak istenilen çalışmalara toplumsal katılımın sağlanabilmesinde önemli bir güç olan kitle iletişim araçlarının hala etkin olarak kullanılmaması ise önemli bir eksiklik olarak gözlemlenmektedir. Oysa kitle iletişim araçları üzerinden sosyal sorunlara yönelik yayın yapılması ve bu konularda kamuoyu oluşturulması medyanın asli görevleri arasında yer almaktadır (Rigel 2000). Çalışmanın ilerleyen bölümlerinde afetler özelinde örneklerle değinilecek toplumsal sorunlarla ilgili medyanın yayınladığı haberlerdeki konuları belirli kısıtlar dâhilinde sunması ise konu hakkında sağlıklı bir kamuoyu oluşmasını engellemektedir. Bu durumun oluşmaması için habere konu olan olayın sadece kendisini değil olası toplumsal etkilerinin de haberi sunan yayın tarafından aktarılması gerekmektedir. Ayrıca bu tarz yayınlar afetlere yönelik yanlış bilgilerin yayılmasını engelleyerek bu alanda dil ve fikir birliğinin ve standarttın oluşmasına yardımcı olacaktır (Kadığlu 2011). Tüm bu gereklilikler ise sonuçları itibariyle toplumun tüm katmanlarını olumsuz etkileyebilecek afetlere karşı yürütülen çalışmalarda kitle iletişim araçları gibi önemli bir gücün etkili ve doğru kullanılması ihtiyacını doğurmakta ve bu çalışmanın gerekliliğini oluşturmaktadır.

\section{Toplumsal Kapasite Geliştirme}

15. yüzyılın erken dönemlerinden itibaren kavram olarak kullanılan kapasite, literatürde etimolojik köken olarak Latince 'capacitatem' ve Fransızca 'capacitê' kelimelerine dayandırılmaktadır (URL-1 2017). Kapasite kavramı Türk Dil Kurumu'na (TDK) göre Fransızca kökeni temel alınarak; “bir şeyi içine alma, sı̆̆dırma sınırı, kapsama gücü, sı̆̆a, belli bir alana slğabilecek kişi veya nesne sayısı, bir işletmenin üretim miktarl, bir kondansatörün elektrik yı̆̆ma sınırı, anlama, kavrama yeteneği " olarak tanımlanmaktadır (Akalın 2011). Misalli Büyük Türkçe Sözlükte ise kapasite kavramı Latince ve Fransızca kökenleri temel alınarak, "bir şeyin diğer şeyleri içine alabilme, içine siğdırabilme derecesi, anlama, kavrama ve idrak etme yeteneği, sı ̆̆a” olarak tanımlanmaktadır (Ayverdi 2010). Gelişim kavramı ise yine TDK'ye göre "gelişme işi, serpilip büyüme, ilerleme, inkişaf, tekâmül, aksiyon" olarak tanımlanmaktadır (Akalın 2011). Aynı kavram Misalli Büyük Türkçe Sözlükte ise "gelişme, serpilip büyüme, neşvünema, ilerleme, inkişaf, tekâmül" olarak açıklamaktadır (Ayverdi 2010). Kapasite ve gelişim kavramlarının bir araya getirilmesi sonucunda yaratılan ve bir çalışma alanı oluşturan kapasite geliştirme kavramı ise az gelişmiş ve gelişmekte olan ülkelerde Dünya Bankası, Birleşmiş Milletler Kalkınma Programı (UNDP), Ekonomik İşbirliği ve Kalkınma Örgütü (OECD)ve Avrupa Komisyonu gibi uluslararası organizasyonların uyguladıkları çalışmalardan elde ettikleri verilere dayandırılarak tanımlanmaktadır. Bu alanda çalışan farklı organizasyonların yaptıkları tanımlamaların organizasyonun kültürünü de kapsaması, ayrıca bu alanda çalışan diğerlerin kavrama yönelik açıklık getirme çabası, kapasite geliştirme ile ilgili çok fazla tanımın ortaya çıkmasına neden olmaktadır.

$\mathrm{Bu}$ farklı kaynaklardan yapılan bazı tanımlamaları incelediğimizde Dünya Bankası kapasite geliştirmeyi; “yerel sahiplenme ve kalkınma hedefine ulaşma çabalarının etkililiğini ve verimliliğini artırmak için politika, sosyo-politik ve örgütsel faktörlerde değişikliklere yol açan, liderler, koalisyonlar ve diğer değişim aktörleri tarafindan yerelde yürütülen 
ögrenme süreci” olarak tanımlamaktadır (OECD 2006). Ekonomik İşbirliği ve Kalkınma Örgütü (OECD)'nün gerçekleştirdiği çalışmalara göre kapasite geliştirme; "bir bütün olarak insanların, örgütlerin ve toplumun, zaman içinde kapasiteyi yaratma, uyarlama, güçlendirme ve sürdürme süreçleri” şeklinde tanımlamaktadır (Otto vd. 2009). Kapasite geliştirmeye yönelik çalışmaları bulunan Derick W. Brinkerhoff bu tanımlara ek olarak; "bir sistemin var olmasını, uyarlanmasını ve gerçekleştirilmesini sağlayan niteliklerin, yeteneklerin ve ilişkilerin gelişen birleşimi” kavramlarının da kapasite geliştirme tanımı içerisinde yer almasını savunmaktadır (Brinkerhoff ve Morgan 2010). Farklı kaynaklardan yapılan tanımlara bakıldığı zaman kapasite geliştirme ile birey, kurum, kent, yerel, bölge veya toplum ölçeklerinde ve farklı düzlemlerde belirlenen amaçlar doğrultusunda büyüme, gelişim veya performansın geliştirilmesinin ve bu gelişimlerin sürdürülebilirliğinin sağlanmasının hedeflendiği görülmektedir.

\subsection{Afetlere Karşı Toplumsal Kapasite Geliştirme}

Dünyanın birçok yerleşim yeri, iklim değişikliğine, jeolojik yapısına, teknolojik donanımlarına ve insani faktörlere bağlı olarak farklı tür ve derecelerde afet ve acil durumlara neden olabilecek risklerle karşı karşıyadır. Bu yerleşim yerlerinde, geçmiş dönemlerde yaşanan afetlerin neden olduğu kayıpların gelecekte de yaşanmaması ve afetlerden dolayı meydana gelebilecek her türlü zararların engellenebilmesi için bir disiplin çevresinde afetlere yönelik toplumsal kapasiteyi geliştirecek sistematik ve planlı çalışmalar yürütülmektedir. Afetlere karşı yürütülecek kapasite geliştirme çalışmalarını Tablo-1'de görüleceği üzere Kadıŏlu üç seviyede sınıflandırmaktadır (Kadıŏlu 2011).

Tablo 1'de sunulan farklı düzey ve katmanlardaki planlamalar ile olası bir afetin neden olacağı tüm kayıpların en aza indirgenmesi, toplumsal direncin en üst seviyeye çıkarılması amaçlanmaktadır. Bu amaca ulaşabilmek için her seviyede hazırlanan planların birbirleri ile entegre olması, toplumsal yapıyı oluşturan kurum - kuruluş, grup, birey gibi unsurların birlikte hareket etmesi gerekmektedir. "Bir toplumun afete hazır ve dirençli hale gelebilmesi için tüm ilgili paydaşların kapasite artırımı konusunda eşgüdümle çalışması gerekmektedir" (Ural 2014). Afetlere karşı dünya genelinde yürütülen çalışmalar incelendiğinde, bu alanda toplumsal kapasite geliştirme faaliyetleri doğrultusunda toplumu harekete geçirebilmenin bazı kriterlerle mümkün olduğu görülmektedir. 'İstanbul Deprem Master Planı'nda deprem özelinde eğitim ve sosyal çalışmalarda kullanılması üzere oluşturulan "güvenilirlik ve inandırıcılık, duygu-düşünce-tutum-beklenti bütününe hitap, deprem tanımını çaresizlik ve korkuyla beklenen felaketten başa çıkılabilecek doğa olayına dönüştürmek, yeterlilik/yapabilirlik bilincini oluşturmak, depreme hazır olmanın bir insan hakkı olduğunu düşündürmek, halk ve yönetim arasında bir dayanışma etiği oluşturmak, halkın değerlerine - yargllarına saygı göstermek, programın ve eğitimin etkinliğini sınamak" kriterlerinin afetlere karşı toplumsal kapasite geliştirme çalışmalarında da dikkate alınması gerekmektedir (Fişek vd. 2003). Uzun bir zaman dilimi içerisinde maliyetli önlemler alınmasını gerektiren afetlere hazırlık çalışmalarında bireyleri harekete geçirebilmek için afetlere karşı toplumsal kapasite geliştirme çalışmalarının bu kriterlerden yoksun olmaması önem arz etmektedir. Kapasite kavramı ve afet zararlarını azaltmayı hedefleyen çalışmaların 1şığında, afetlere karşı toplumsal kapasite geliştirme, afet riski altındaki bir toplumu oluşturan tüm katmanların tüm imkân ve olanaklarının planlı ve sistemli bir şekilde birbirleri ile eşgüdümlü olarak en etkili kullanımına olanak sağlayan, toplumsal direnci en üst seviyeye çıkararak tüm kayıpları en aza indirgemeyi hedefleyen önleme, koruma ve müdahale faaliyetleri ve bunlara yönelik yapılan yatırımların tamamı olarak tanımlanabilmektedir

Tablo 1: Farklı Seviyedeki Kurum ve Kuruluşların Afetlere Hazırlık Için Yapması Gerekenler

\begin{tabular}{|l|l|c|c|}
\hline Planın Düzeyi & Planın Kapsamı & $\begin{array}{c}\text { Planın } \\
\text { Önemi }\end{array}$ & $\begin{array}{c}\text { Planın Uygulama } \\
\text { Alanı }\end{array}$ \\
\hline Stratejik & Politika, Hedefler-Öncelikler, Destek, Gelecek İçin Planlar & Altın & Ülke \\
\hline Taktiksel & $\begin{array}{l}\text { Önceliklerin Uygulanması, Olay Yeri İle İlgili Talimatlar, } \\
\text { Olay Yeri İle İlgili Faaliyetlerin Koordine Edilmesi }\end{array}$ & Gümüş & Bölge/İl/İlçe \\
\hline Operasyonel & Uygulamalı, Arama ve Kurtarma, Güvenlik, Emniyet & Bronz & Olay Yeri \\
\hline
\end{tabular}

\section{Haber Yayıncılığı ve Toplumsal Bilgi Edinme İhtiyacının Karşılanması}

İlk başlarda informal bir yapıda ve çok daha uzun zaman dilimlerinde gerçekleşen haber alma çabası küreselleşen dünyayla birlikte mesafelere bakılmadan anlık olarak gerçekleşmekte ve günümüz modern toplumlarında temel bir hak olarak kabul edilmektedir. Demokratik bir hak olarak görülen haber kavramıyla ilgili farklı kaynaklarda çeşitli tanımlamalar yapılmaktadır. Wilbur Schramm haberi, "insanların kafalarında oluşmaktadır. Başka bir deyişle haber, düşünsel bir boyuta subjektif bir yapıya sahiptir” diye ifade etmektedir (Parsa 1993). 'Gazeteciğe Giriş’ kitabında ise "haber, güncel bir olayın gerçeğe uygun bir şekilde iletişim araçları vasıtasıyla sunulması" şeklinde tanımlanmaktadır (Schlapp 2002). Hangi olayların haber niteliği taşıdığının ölçüleri ise ilk kez 1922'de, A.B.D.’li siyasetçi Walter Lippmann'ın 'Kamuoyu' adlı eserinde "günlük haberler o günün olaylarının temsili bir dökümünü oluşturmamaktadır, gazeteciler ya da televizyoncular bazı olayları görmezden gelerek bu olaylar arasında seçim yapmaktadır” şeklinde belirtmektedir (Toruk 2008). Kemal Aslan ise 'Haberin Yol Haritası' isimli kitabında haber değeri kriterlerini “'zamanlılık, önemlilik, insani ilgi, ilginçlik, görsel işitsel etki” olarak beş başlıkta toplamaktadır (Aslan 2009). 
Haberin, hedef kitlelerin tamamına ulaştırılabilmesi için farklı mecralara yönelik hazırlanması gerekliliği ise bir başka unsur olan iletişim araçlarının önemini ortaya çıkarmaktadır. Bu nedenle haber alma ihtiyacını karşılayan iletişim araçları da en az habere ulaşım kadar özel bir yer edinmektedir. Yaygın olarak kullanılmakta olan ve bu çalışma için önem arz eden gazete ve televizyon ise iletişim araçları içerisinde toplumun habere ulaşmada en çok tercih ettiği araçlar arasında yer almaktadır. Bu iki iletişim aracı için yapılan haberler arasında ise bazı farklar bulunmaktadır. Nihayetinde ise birçok kriterin birlikte sağlanmaya çalışıldığı ve bazı dönemlerde bazı kriterlerin baskın hale gelmesi ile şekillenen haber içerikleri olayın çıplak halinden başka bir boyut ile izleyiciye/okuyucuya sunulmaktadır.

\subsection{Haberde Çerçeveleme Kuramı}

Olayın kendisinden ziyade sunuş şeklinin öne çıktığı, haber yapılırken bazı sözcüklerin ve görsellerin ön plana çıkarılarak ya da metaforlarla sunularak çerçevelendiği bilinen bir gerçekliktir. Kavramsal olarak çerçevelemeyi ilk inceleyen ve bu konuda literatürde referans yayın haline gelen "Frame Analysis" (1974) kitabının yazarı olan Erving Goffman’ın yaptığı tanıma göre çerçeveleme, olayları sınırlamayı bu olaylar içerisindeki bazı konuların ön plana çıkartılmasını sağlamaktadır (Erdoğan 2001). Çerçevelemeyi medya araçları alanında tanımlayan ilk araştırmacılardan biri olan Gitlin, "medya çerçeveleri dünyayı haberciler için düzene sokar, haberciler de bunu kendilerinin haberlerine bağımlı olan izler kitleye aktarmak suretiyle sosyal dünyaya bir düzen getirir" diyerek haber ve haber tüketicilerinin birbirlerini nasil etkilediklerini açıkça belirtmektedir (Özarslan ve Güran 2015). Çerçeveleme kavramı, 1990'larda Robert Entman'ın bu alanda yaptığı çalışmalar sayesinde kuram halini almıştır. Entman, çerçeveleme yönteminde 'seçme' ve 'dikkat çekme' olarak iki temel sürecin olduğunu belirtmektedir (Seyidov 2014).

\section{Materyal ve Yöntem}

Çalışma kapsamında, 21.07.2017 tarihinde Akdeniz Gökova Körfezi'nde saat 01:31'de meydana gelen ve medyada "Bodrum Depremi” örnek olay olarak seçilmektedir. Depremin meydana geldiği tarihte bölge nüfusunun yoğun olması ve ticari faaliyet yürüten kuruluş fazlalığı, depremin akabinde tsunami oluşması ve afetin sadece depremden ibaret olmadığını, depremlerin ikincil riskleri ve diğer afet türlerini nasıl etkileyebileceğini göstermesi Bodrum Depremi’nin örnek olay olarak seçilmesinde etkili olmaktadır. Seçilen örnek olay, Türkiye'de en çok izlenme oranına sahip ilk üç ana haber programı ve en çok okunma oranına sahip ilk üç gazete ana sayfasında haber olarak sunumu, kullanılan çerçeveleme yaklaşımı ve toplumsal kapasite geliştirmeye etkisi bağlamlarında değerlendirilmektedir. Değerlendirmeler olayın haber olarak sunumunda kullanılan metin ve içerikler, görsel ve hacim, kelime sayısı, süre ve alan oranı ve gündemde kalma süresi ölçütlerine göre yapılmakta ve ulaşılan veriler niteliksel ve niceliksel olarak analiz edilmektedir. Seçilen gazetelerin incelenme tarih aralığı olayın ilk ve son haber olma tarihleri arasındaki süre dikkate alınarak yapılmaktadır. Televizyon haberleri ise olayın gerçekleşmesinden sonra yapılan ilk ana haber programları kapsamında değerlendirilmektedir.

\section{Akdeniz Gökova Körfezi Sismik Hareketliliği Gazete ve Televizyon Haber İçerikleri}

Boğaziçi Üniversitesi Kandilli Rasathanesi ve Deprem Araştırma Enstitüsü Bölgesel Deprem-Tsunami İzleme ve Değerlendirme Merkezi verilerine göre "21 Temmuz 2017 tarihinde Gökova Körfezi - Akdeniz'de yerel saat ile 01:31'de aletsel büyüklüğ̈̈ $M w=6.5$ (Ml=6.2) olan şiddetli bir deprem meydana gelmiştir. Depremin odak derinliği yaklaşık $5 \mathrm{~km}$ civarında olup sığ odaklı bir depremdir. Deprem Muğla ili ve ilçeleri başta olmak üzere tüm Güney Batı Ege’de hissedilmiştir" (URL-2 2018). Deprem sonrasında özellikle Bodrum'un sahil kesimlerinde depreme bağlı tsunami dalgaları nedeniyle maddi kayıplar yaşanmıştır. Medyada 'Bodrum Depremi’ olarak haber olan sismik hareketliliğin ve akabinde oluşan tsunaminin Türkiye'de en yüksek tiraja sahip ilk üç gazete olan Hürriyet, Sabah, Sözcü (URL-3 2018) gazetelerinin 21-25.07.2017 tarihleri arasında ana sayfalarında yer alan haber analizleri yapılmakta ve afetlere karşı toplumsal kapasite geliştirmeye etkisi değerlendirilmektedir. Televizyon haber içeriklerinde ise Türkiye'de en yüksek izlenme oranına sahip ilk üç ana haber programı olan Show TV, Fox TV, ATV (URL-3 2018) ana haber programlarındaki işlenişlerinin analizleri yapılmakta ve afetlere karşı toplumsal kapasite geliştirmeye etkisi değerlendirilmektedir. Değerlendirmeler, ulusal düzeyde yayınlanan ana haber programlarının depremin meydana geldiği tarihi (21.07.2017) kapsayan AB, TOTAL, ABC1 İzleyici Gruplarında Rating oranları dikkate alınarak yapılmaktadır.

\subsection{Gazete Haber İçerikleri}

Sabah, Hürriyet ve Sözcü Gazetelerinin ana sayfalarında, yayınlanan haberlerin; metin ve içerikleri (haberin başlığ1, haberin başlık altı yazısı, haberin alt başlıkları, haber metin içerikleri), görseller ve hacim (haberde kullanılan fotoğraflar, haberin konumu, ana sayfa alanı, haber alanı), görsel ve kelime sayılarından (toplam, afet hazırlık) oluşan veriler, Tablo 2, Tablo 3 ve Tablo 4 'te sunulmaktadır. 
Tablo 2: 21, 22, 23 ve 24.07.2017 Tarihli Sabah Gazeteleri ana sayfa haber incelemeleri

\begin{tabular}{|c|c|c|c|c|c|c|}
\hline \multirow{2}{*}{\multicolumn{3}{|c|}{$\begin{array}{c}\text { Gazete Adı } \\
\text { Yayın Tarihleri }\end{array}$}} & \multicolumn{4}{|c|}{ Sabah Gazetesi (2017) } \\
\hline & & & 21.7 & 22.7 & 23.7 & 24.7 \\
\hline \multirow{12}{*}{ 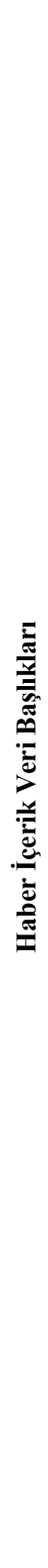 } & \multirow{4}{*}{ 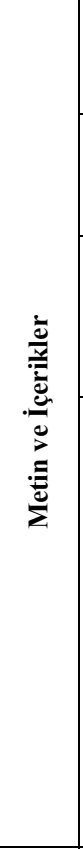 } & 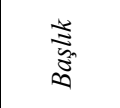 & \multirow{12}{*}{ 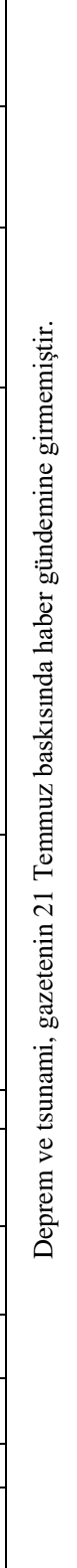 } & $\begin{array}{l}\text { Kos'ta Deprem Bodrum'da Tsunami, } \\
\text { Deprem (Yavuz Donat köşe yazısı) }\end{array}$ & $\begin{array}{l}\text { Kara Ada Tsunamiye Set } \\
\text { Oldu }\end{array}$ & $\begin{array}{l}\text { Hasar Tespiti (Yavuz } \\
\text { Donat köşe yazısı) }\end{array}$ \\
\hline & & 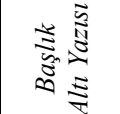 & & $\begin{array}{l}\text { Gökova Körfezi'ndeki } 6.6 \text { büyüklüğündeki deprem Kos } \\
\text { Adası'nı yıkarken, Bodrum'daki panik, } 40 \text { santimi bulan } \\
\text { tsunamiyle katlandı. }\end{array}$ & -------- & -------- \\
\hline & & $\frac{\bar{\pi}}{\frac{3}{\sqrt[3]{n}}}$ & & $\begin{array}{l}\text { Kos'ta Biri Türk İki Kişi Öldü, Deniz } 100 \text { Metre İçeri Girdi, } \\
\text { Kos'taki Tatilci Türkler Feribotla Getirildi, Bodrum'u } \\
\text { Deprem Yönetmeliği Kurtardı, Kos'ta Ölen Türk vatandaş1 } \\
\text { (adı soyadı haber kaynağında verilmektedir) İzmir'de Kafe } \\
\text { İsletiyordu. }\end{array}$ & -------- & ----- \\
\hline & & 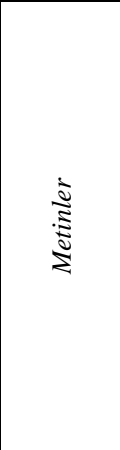 & & $\begin{array}{l}\text { Gece yarısı Gökova'yı } 16 \text { saniye sallayan } 6.6 \text { büyüklüğündeki } \\
\text { depremde en büyük yıkım Kos Adası'nda oldu. Tarihi } \\
\text { caminin yıkılan minaresi altında kalan Türk turist (adı soyadı } \\
\text { haber kaynağında verilmektedir)ile bir İsveçli öldü. Ağıı } \\
\text { yaralanan bir Türk de Atina'ya gönderildi. Başta Bodrum ve } \\
\text { Datça olmak üzere bölgede büyük panik yaratan depremde } \\
345 \text { kişi yaralandı. Bodrum'da 30-40 santime ulaşan tsunami } \\
\text { oluștu. } 100 \text { metre içeri giren deniz suları tekne ve araçları } \\
\text { sürükledi, ev ve otelleri su bastı Kos Adası'ndaki tarihi } \\
\text { Defterdar Camisi'nin minaresi yıkılld. Bodrumda arabalar } \\
\text { büyük hasar gördü. Hadise dişarıda sabahladı, Tsunami } \\
\text { Bodrum'da birçok tekneyi karaya savurdu. Zangır zangir... Ev } \\
\text { zangır zangır sallanıyor. Arada yerin altından ses geliyor... } \\
\text { Güm gümgüm. Dişarıda sabahliyoruz. Herkes gibi. }\end{array}$ & $\begin{array}{c}\text { Muğla } 6.6 \\
\text { büyüklüğ̈ndeki depremin } \\
\text { ardından en etkilisi } 5.0 \\
\text { olan } 500 \text { 'e yakın artçı } \\
\text { depremle sarsıldı. } \\
\text { Vatandaşlar geceyi } \\
\text { dışarıda geçirdi. Bu arada } \\
\text { Bodrum'a } 3 \text { mil } \\
\text { mesafedeki Kara Ada'nın } \\
\text { dalga kıran rolüyle } \\
\text { tsunami sularının etkisini } \\
\text { kırdığı belirtildi. }\end{array}$ & $\begin{array}{l}\text { Bodrum'da bu } \\
\text { şiddetindeki depremde } \\
\text { duvar bile çatlamadiysa, } \\
\text { inşaat sektörüne aferin } \\
\text { demek gerekiyor. }\end{array}$ \\
\hline & \multirow{4}{*}{ 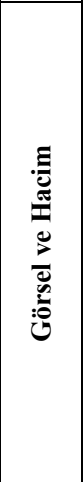 } & 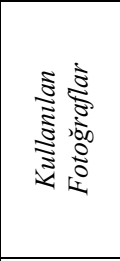 & & $\begin{array}{c}\text { Görsel -1: Kos Adası'ında minaresi yıkılan tarihi cami. } \\
\text { Görsel -2: Kos Adası'nda ölen Türk Gencinin fotoğrafi. } \\
\text { Görsel -3: Hasar görmüş bir otomobil. } \\
\text { Görsel -4: Karaya oturmuş ve hasar görmüş tekneler. } \\
\text { Görsel -5: Kanala sıkışmış bir minübüs. } \\
\text { Görsel -6: Gece, açık alanda yataklar, uyuyan ve oturan } \\
\text { insanlar. } \\
\text { Görsel -7: Gündüz, yataklar ve uyuyan insanlar. }\end{array}$ & $\begin{array}{l}\text { Görsel -1: Gündüz, } \\
\text { kaldırımda yataklar, } \\
\text { uyuyan insanlar. }\end{array}$ & $\begin{array}{l}\text { Görsel -1: Köşe } \\
\text { yazarının fotoğrafı ve } \\
\text { haber başlı̆̆ı. }\end{array}$ \\
\hline & & Копити & & Sol ilk sütun hariç orta alan & Alt orta alan & Sağ alt köşe \\
\hline & & $\begin{array}{l}\text { Ana } \\
\text { Sayfa } \\
\text { Alanı }\end{array}$ & & $\begin{array}{l}30,8(\mathrm{~cm}) \times 52.5(\mathrm{~cm}) \\
\quad=1.617\left(\mathrm{~cm}^{2}\right)\end{array}$ & $\begin{array}{l}30,8(\mathrm{~cm}) \times 52.5(\mathrm{~cm}) \\
\quad=1.617\left(\mathrm{~cm}^{2}\right)\end{array}$ & $\begin{array}{l}30,8(\mathrm{~cm}) \times 52.5(\mathrm{~cm}) \\
\quad=1.617\left(\mathrm{~cm}^{2}\right)\end{array}$ \\
\hline & & $\begin{array}{l}\text { Haber } \\
\text { Alanı }\end{array}$ & & $\begin{array}{c}24,8(\mathrm{~cm}) \times 21,2(\mathrm{~cm})+3,1(\mathrm{~cm}) \times 6,8(\mathrm{~cm}) \\
=546,84\left(\mathrm{~cm}^{2}\right)\end{array}$ & $\begin{array}{l}15,5(\mathrm{~cm}) \times 7,9(\mathrm{~cm}) \\
\quad=122,45\left(\mathrm{~cm}^{2}\right)\end{array}$ & $\begin{array}{l}6,8(\mathrm{~cm}) \times 2,7(\mathrm{~cm}) \\
\quad=18,36\left(\mathrm{~cm}^{2}\right)\end{array}$ \\
\hline & \multirow{2}{*}{ 离离 } & Toplam & & 8 & 1 & 1 \\
\hline & & \begin{tabular}{|c|} 
Afete \\
Hazırlık \\
\end{tabular} & & 0 & 0 & 0 \\
\hline & \multirow{2}{*}{ 竞 } & Toplam & & 157 & 39 & 14 \\
\hline & & $\begin{array}{c}\text { Afete } \\
\text { Hazırlık }\end{array}$ & & 4 & 0 & 0 \\
\hline
\end{tabular}

21 Temmuz 2017 tarihinde gece saat 01:31'de meydana gelen depremin ve akabinde gerçekleşen tsunaminin Sabah Gazetesinin aynı tarihli baskısında yer almadığı görülmektedir. 22 Temmuz 2017 tarihli baskıda yer alan deprem haberine, gazete ana sayfasının 3 'te 1 oranından biraz fazla bir alan ayrılmaktadır. Haberde, depremin ve akabinde meydana gelen tsunaminin nerede daha fazla zarara neden olduğu ön plana çıkarılan bir başlık kullanılmaktadır. Başlık altı açıklama yazısında bu durum detaylandırılarak depremin Kos Adası'ndaki yıkıcı etkisi ve tsunaminin de Bodrum'da neden olduğu panik açıkça belirtilmektedir. Haberin alt başlıklarında ise deprem ve tsunami anına yönelik Kos Ada'sı ve Bordum özelinde bazı sayısal ve durum tanımlamaları ile ilgili veriler, Bodrum' da yapısal hasarın düşük olma nedeni ve ölen Türk vatandaşına yönelik bilgi paylaşılmaktadır. Alt başlıklar içerisinde yer alan "Bodrum'u Deprem Yönetmeliği Kurtardı" başlığı ile deprem bölgelerinde yapılacak "Deprem Bölgelerinde Yapılacak Binalar Hakkında Yönetmelik"e atıf yapılmakta ve yapısal hazırlığın önemi vurgulanmaktadır. Haber içerisinde kullanılan metinlerde ise deprem ve tsunami olaylarına ve sonrasında neden olduğu hasarlara yönelik niceliksel ve niteliksel bilgiler ve durum değerlendirmeler aktarılmaktadır. Ayrıca metin içerisinde geçen "zangır zangır sallanıyor", "güm güm sel geliyor" gibi ifadelerle olayın bölge halkında yarattığı etkiler betimlenmeye çalışılmaktadır. Haberde toplam kullanılan 157 kelime içerisinde sadece 4 tanesinin kullanımı ile oluşturulan cümlede "Bodrum'u Deprem Yönetmeliği Kurtardı” afetlere yönelik toplumsal kapasite geliştirme kapsamında değerlendirilecek bir paylaşım yapılmaktadır. 
Haber ile birlikte kullanılan görsellerde ise deprem ve tsunaminin neden olduğu yapısal ve araçlar üzerindeki hasarları ile birlikte ölen Türk vatandaşı fotoğrafı paylaşılmaktadır. Toplam 7 görselin bulunduğu haberde afetlere kaşı direncin ve kapasitenin geliştirilmesinin desteklendiği herhangi bir görsel bulunmamaktadır. Olayın gazete ana sayfası üzerinde kapladığı alan ve konumu değerlendirildiğinde olayın gazete tarafindan haber değerinin yüksek olarak algılandı $\breve{g}_{1}$ gözlemlenmektedir. 23 Temmuz 2017 tarihli Sabah Gazetesi ana sayfasında olaya toplam ana sayfa alanının 13'te 1 oranından biraz az bir alanın ayrıldığı görülmektedir. Haber başlığında tsunaminin daha büyük zararlara neden olabileceği ancak bölgenin jeolojik yapısından dolayı olayın daha az hasarla atlatıldığı ifade edilmeye çalışılmaktadır. Haberin metninde ise ilk deprem sonrası bölgede yaşanan sismik hareketlilikler rakamsal olarak ve bölge halkının durumu aktarılmakta, haber başlığında belirtilen jeolojik özellik tekrarlanmaktadır.

Toplam 39 kelime ile aktarılan haberde afetlere karşı toplumsal kapasite geliştirme ile ilgili anlamlı bir bütün oluşturabilecek herhangi bir ifade kullanılmamaktadır. Haberde açık alanda uyuyan insanların olduğu bir fotoğraf kullanılarak bölge halkının tedirginliklerinin devam ettiği gösterilmektedir. Habere ayrılan alan ve ana sayfa üzerindeki konumu değerlendirildiğinde ise gazete tarafından olaya verilen haber değerinin azaldığı gözlemlenmektedir. Gazetenin 24 Temmuz 2017 tarihli baskısında ise olaya ana sayfanın toplam alanının 88'de 1 oranında bir alanın ayırdı ̆̆ görülmektedir. Köşe yazısı olarak ele alınan olaya yönelik 14 kelimeden oluşan açıklamada inşaat sektörünün Bodrum Bölgesinde yaptığı yapıların deprem dayanımlarına atıfta bulunulmaktadır. Depreme karşı yapısal dayanımın öneminin belirtilmesinden dolayı köşe yazısı bilgilendirme içeriği afetlere karşı toplumsal kapasite geliştirmeyi desteklemektedir. Ancak dolaylı olarak ifade edilmesinden dolayı değerlendirme kapsamına alınmamaktadır. Olaya ait bir fotoğrafın paylaşılmadığı içeriğin köşe yazısı olması olayın gazetenin haber gündeminden çıktığı ve köşe yazarının özel değerlendirmesi bağlamında incelendiği görülmektedir. Olayın köşe yazısı bağlamında ana sayfada yer alması konum ve kapladığı alan değerlendirmesinden ziyade gazetenin ana sayfasında ortalama iki köşe yazarına yer verilmesi nedeniyle köşe yazısı içeriğinin gazete tarafından önemsendiğini göstermektedir. 21 Temmuz 2017 tarihinde meydana gelen deprem ve tsunami olaylarına ait herhangi bir haber veya içerik 25 Temmuz 2017 tarihinde yayınlanan Sabah Gazetesi ana sayfasında yer almamaktadır. 
Tablo 3: 21, 22, 23 ve 24.07.2017 Tarihli Hürriyet Gazeteleri ana sayfa haber incelemeleri

\begin{tabular}{|c|c|c|c|c|c|c|}
\hline \multirow{2}{*}{\multicolumn{3}{|c|}{$\begin{array}{c}\text { Gazete Adı } \\
\text { Yayın Tarihleri }\end{array}$}} & \multicolumn{4}{|c|}{ Hürriyet Gazetesi (2017) } \\
\hline & & & 21.7 & 22.7 & 23.7 & 24.7 \\
\hline & & 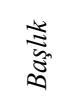 & Bodrum'da Deprem (6.3) & Bodrum Tsunamisi, Ege'de Deprem 6.5 & $\begin{array}{l}\text { Belediye Başkanından } \\
\text { Davet, Bodrum'a } \\
\text { Devam }\end{array}$ & \\
\hline & & 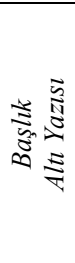 & $\begin{array}{l}\text { Ege Denizi'nde Bodrum Datça } \\
\text { arasında 01:31'de } 6.3 \\
\text { büyüklügünde deprem meydana } \\
\text { geldi. Yürekleri ağıza getiren } \\
\text { sarsıntı Ege'den Akdeniz'e kıyı } \\
\text { hattında birçok ilde hissedildi. } \\
\text { Elektrikler kesildi, yüzbinler } \\
\text { sokaklarda sabahladı. }\end{array}$ & $\begin{array}{c}\text { Ege Denizi'ni sarsan depremle oluşan } 1.5 \\
\text { metrelik dalga, sabaha karşı Gümbet'i } \\
\text { vurdu. Ve Türkiye, yakın tarihinin ilk } \\
\text { 'tsunami' felaketini ucuz atlattı. }\end{array}$ & $\begin{array}{l}\text { Ege'de meydana gelen } \\
6.5 \\
\text { büyüklüğ̈ndeki } \\
\text { depremin ardından } \\
\text { Bodrum'da hayat } \\
\text { normale döndü }\end{array}$ & \\
\hline & & 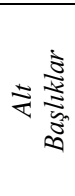 & Dalgalar Otellere Ulaştı & $\begin{array}{l}\text { Türk gencini (adı soyadı haber kaynağında } \\
\text { verilmektedir) Ölüm Kos'ta Yakaladı, } \\
\text { Gümbet'te Şezlong Denizi, } 358 \text { Kişi } \\
\text { Hastanelik, 250 Artçı Sarsıntı Oldu, Güney } \\
\text { Ege'yi Fena Salladı, Kıyıdan } 100 \text { Metre } \\
\text { İçeri Girdi, AFAD Kandilli Farkı }\end{array}$ & $\begin{array}{l}\text { Başkan Kocadon: } \\
\text { Buyrun Gelin }\end{array}$ & \\
\hline 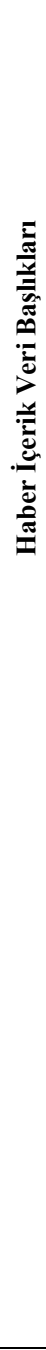 & 离 & 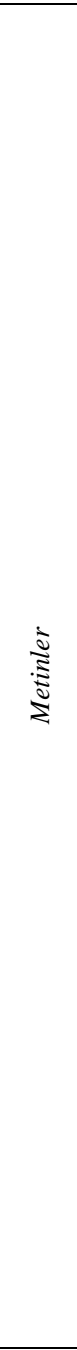 & $\begin{array}{l}\text { Muğla Valisi Esengül Civelek, } \\
\text { "korkarak atlayanlardan } \\
\text { hastanelerimize gelenler oldu. } \\
\text { Kent genelinde şuan için olumsuz } \\
\text { bir şey yok" dedi. Bodrum } \\
\text { Belediye Başkanı Mehmet } \\
\text { Kocadon ve Datça Belediye } \\
\text { Başkanı Gürsel Uçar, çok şiddetli } \\
\text { bir sarsıntı meydana geldiğini, } \\
\text { merkezlerde herhangi bir yıkım } \\
\text { olmadığını söyledi. Kıyıda büyük } \\
\text { dalgalar oluşurken, sahil otellerini } \\
\text { su bastı. Trafolarda yangın çıtı. } \\
\text { Depremin hemen ardından } \\
\text { 01:37'de } 4.2,01: 52 \text { 'de } 4.6 \text { ve } 4.4 \text {, } \\
\text { 02:00'de de } 3.8 \text { olmak üzere } 5 \\
\text { büyük artçı sarsıntı meydana } \\
\text { geldi. }\end{array}$ & $\begin{array}{l}\text { Depremin iki kurbanı da Yunanistan'ın Kos } \\
\text { (İstanköy) Adası'ndandı. Doğum gününü } \\
\text { kutlaması için tatile giden (adı soyadı ve } \\
\text { yaşı haber kaynağında verilmektedir), } \\
\text { adanın merkezindeki Cezayirli Hasan Paşa } \\
\text { Camisi'nin yıkılan minaresi altında can } \\
\text { verdi. Diğer kurbanın da İsveçli bir turist } \\
\text { olduğu açıklandı. Kos'taki Türkler 'den } \\
\text { 211'i iki sefer yapan feribotla Türkiye'ye } \\
\text { döndü. Ölen gencin (adı soyadı haber } \\
\text { kaynağında verilmektedir) acı haberi } \\
\text { İzmir'deki ailesini yasa boğdu. Tsunami } \\
\text { dalgası sürüklediği bazı arabaları yaklaşık } 2 \\
\text { metre yükseğe çıkaracak kadar güçlüydü. } \\
\text { Depremin en şiddetli hissedildiği yer } \\
\text { Bodrum ve Datça oldu. Datça'da eski bir taş } \\
\text { bina yıkıldı, Bodrum'da evlerde çatlaklar } \\
\text { oluştu, istinat duvarları yıkıldı, 358 kişi } \\
\text { hastanelere başvurdu. Bodrum kıyılarını ise } \\
\text { dün sabah tsunami dalgalarının denize } \\
\text { çektiği şezlong ve ağaç parçaları doldurdu. } \\
\text { En büyüğü dün akşam olan ve AFAD'ın } 5 \\
\text { büyüklüğünde ölçtüğü artçı sarsıntılar250'yi } \\
\text { buldu. Bölge halkı ve tatilciler geceyi } \\
\text { sokak, bar ve sahilde geçirdi. Bodrum } \\
\text { açıklarında dün saat } 01: 31 \text { 'de olan ve } 11 \\
\text { saniye süren } 6.5 \text { büyüklüğündeki deprem } \\
\text { Yunanistan'ın Kos Adas'nda biri Türk } 2 \\
\text { can aldı. Bodrum, Marmaris, Datça başta } \\
\text { Güney Ege'de halkı sokaklara döktü. } \\
\text { Deprem dehşetini sık sık yaşayan Türkiye, } \\
\text { yakın tarihinde ilk defa 'tsunami'yle de } \\
\text { tanıştı. AFAD'ın yüksekliğini } 1 \text { - } 1.5 \text { metre } \\
\text { olarak verdiği 'deprem dalgası' Gümbet'te } \\
\text { karadan 100 metre içeri girdi. } 3 \text { dakika } \\
\text { süren dalga, } 12 \text { tur ve } 5 \text { balıkçı teknesini } \\
\text { karaya çıkardı. } 30 \text { kadar otomobil de deniz } \\
\text { suları ile yollara sürüklendi, birçok mekânı } \\
\text { su bastı. Mini tsunamide can kaybı olmadı. } \\
\text { Kandilli: Depremin büyüklügü } 6.6 \text {, tsunami } \\
\text { 30-40 cm arası. AFAD: Depremin } \\
\text { büyüklüğü } 6.5 \text {, tsunami 1-1.5 metre. }\end{array}$ & $\begin{array}{l}\text { Belediye Başkanı } \\
\text { Mehmet Kocadon, } \\
\text { Hürriyet'e 'deprem } \\
\text { uzmanlarının söylediği } \\
\text { gibi şuanda Türkiye'nin } \\
\text { en güvenilir yeri } \\
\text { Bodrum. Bodrum } \\
\text { depreme dayanıklı } \\
\text { bölgedir. Kimse tatilini } \\
\text { yarım bırakmasın, } \\
\text { rezervasyonunu iptal } \\
\text { etmesin. Buyrun gelin. } \\
\text { Sloganımız: Tatile, } \\
\text { eğlenmeye, } \\
\text { güneşlenmeye, denize } \\
\text { devam' dedi. }\end{array}$ & 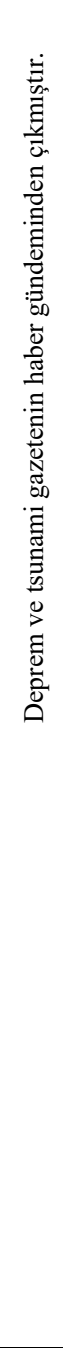 \\
\hline
\end{tabular}




\section{Tablo 3’ün devamı}

\begin{tabular}{|c|c|c|c|c|}
\hline \multirow[t]{4}{*}{ 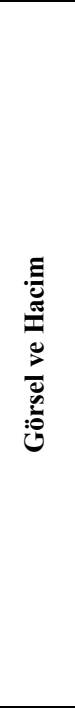 } & 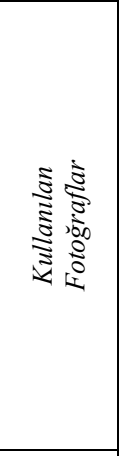 & $\begin{array}{l}\text { Görsel -1: Gece bina girişinde } \\
\text { merdivenlerde bekleyen insanlar. } \\
\text { Görsel -2: Depremin merkez } \\
\text { üssünü gösteren sismik harita. }\end{array}$ & $\begin{array}{c}\text { Görsel -1: Kos Adası'ında minaresi yıkılan } \\
\text { tarihi cami. } \\
\text { Görsel -2: Kos Adası'nda ölen Türk } \\
\text { Gencinin fotoğrafı. } \\
\text { Görsel -3: Yol kenarında hasar görmüş bir } \\
\text { otomobil ve yanında bekleyen insan. } \\
\text { Görsel -4: Denizde yüzen şezlonglar, } \\
\text { şemsiyeler ve çeşitli nesneler. } \\
\text { Görsel -5: Depremin merkez üssünü } \\
\text { gösteren sismik harita. } \\
\text { Görsel -6: Gece, kaldırım kenarında oturan } \\
\text { kucağında bebek olan kadın ve diğer } \\
\text { kadınlar. } \\
\text { Görsel -7: Limanda devrilmiş olmuş tekne. }\end{array}$ & $\begin{array}{l}\text { Görsel -1: Denizde } \\
\text { yüzen insanlar ve } \\
\text { sahilde güneşlenen } \\
\text { insanlar. }\end{array}$ \\
\hline & Копити & Sol üst köşe & Orta alanın tamamı & Alt orta alan \\
\hline & $\begin{array}{l}\text { Ana } \\
\text { Sayfa } \\
\text { Alanı }\end{array}$ & $\begin{array}{l}30,8(\mathrm{~cm}) \times 52.5(\mathrm{~cm}) \\
\quad=1.617\left(\mathrm{~cm}^{2}\right)\end{array}$ & $\begin{array}{l}30,8(\mathrm{~cm}) \times 52.5(\mathrm{~cm}) \\
\quad=1.617\left(\mathrm{~cm}^{2}\right)\end{array}$ & $\begin{array}{l}30,8(\mathrm{~cm}) \times 52.5(\mathrm{~cm}) \\
\quad=1.617\left(\mathrm{~cm}^{2}\right)\end{array}$ \\
\hline & $\begin{array}{l}\text { Haber } \\
\text { Alanı }\end{array}$ & $\begin{array}{l}11,3(\mathrm{~cm}) \times 13,4(\mathrm{~cm}) \\
\quad=151,42\left(\mathrm{~cm}^{2}\right)\end{array}$ & $\begin{array}{c}30,1(\mathrm{~cm}) \times 21,3(\mathrm{~cm}) \\
=641,13\left(\mathrm{~cm}^{2}\right)\end{array}$ & $\begin{array}{l}11,5(\mathrm{~cm}) \times 12(\mathrm{~cm}) \\
\quad=138\left(\mathrm{~cm}^{2}\right)\end{array}$ \\
\hline \multirow{2}{*}{ 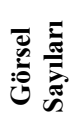 } & Toplam & 2 & 7 & 1 \\
\hline & $\begin{array}{c}\text { Afete } \\
\text { Hazırlik }\end{array}$ & 0 & 0 & 0 \\
\hline \multirow{2}{*}{ 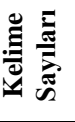 } & Toplam & 105 & 285 & 55 \\
\hline & $\begin{array}{c}\text { Afete } \\
\text { Hazırlık }\end{array}$ & 0 & 0 & 0 \\
\hline
\end{tabular}

21 Temmuz 2017 tarihinde gerçekleşen deprem ve tsunami olayı Hürriyet Gazetesi’nin aynı tarihli baskısında haber olarak yer edinmektedir. "Bodrum'da Deprem 6.3” başlı̆̆ ile yayımlanan habere gazete ana sayfasının 10'da 1 oranından biraz fazla bir alan ayrılmaktadır. Haberin başlığında ve başlık altı açıklama bölümünde depremin oluş saati ve büyüklüğü ile ilgili sayısal veriler ve deprem sonrası hakkında durum tanımlamaları yapılmakta ve tsunami ile ilgili bilgiler paylaşılmamaktadır. Yine bir durum tanımlaması yapılan haberin alt başlığında "Dalgalar Otellere Ulaştı" ifadesi kullanılmaktadır. Haber içerik metinlerinde ise yetkililerin açıklamalarına yer verilmekte deprem ve büyük dalgaların neden olduğu hasarlar aktarılmakta ve deprem sonrası meydana gelen artçı sarsıntılar ile ilgili sayısal veriler paylaşılmaktadır. Toplam 105 kelime ile aktarılan haberin tamamında afetlere yönelik toplumsal kapasite geliştirme ile ilgili anlamlı bir bütün oluşturabilecek herhangi bir ifade kullanılmamaktadır. Haberde bina dişında bekleyen ve oturan insanların olduğu bir fotoğraf ile birlikte Bodrum ve çevresinin haritası üzerinde depremin merkez üssü verilmektedir. 2 görsel ile birlikte servis edilen haberde afetlere yönelik kapasite geliştirmeyi destekleyen herhangi bir görsel bulunmamaktadır. Haberin konumu değerlendirildiğinde olayın gazete tarafından haber değerinin yüksek, kapladığı alan değerlendirildiğinde ise haber değerinin düşük olarak görüldüğü gözlemlenmektedir.

Gazetenin 22 Temmuz tarihli baskısında olaya ana sayfanın 3'te 1 oranından fazla bir alan ayrıldığ görülmektedir. Haber "Bodrum Tsunamisi, Egede Deprem 6.5" başlığı ile yayımlanmakta ve başlıkta tsunami etkisi vurgulanmaktadır. Haberin başlık altı yazısında depremin hissedildiği alan ve neden olduğu tsunami ve oluş zamanına yönelik sayısal veriler verilerek olayın yakın tarihte ilk kez gerçekleştiği belirtilmekte ve "ucuz atlatıldı" denilerek olayın büyük bir yıkıma neden olmadığı ifade edilmektedir. Haberde kullanılan alt başlıklarda ölen Türk vatandaşı, tsunami dalgalarının denize taşıdığı eşyalar, olaya ve sonuçlarına yönelik sayısal veriler, depremin etki bölgesi ve ilgili kurumların depreme yönelik farklı verileri paylaşması öne çıkarılmaktadır. Haber içerik metinlerinde ise deprem nedeniyle hayatını kaybedenlere ve oluşan hasar yönelik bilgiler, Kos Adası'ndaki Türk vatandaşlarının tahliyesine yönelik çalışmalar aktarılmaktadır. Olayın sonucuna yönelik sayısal ve durumsal verilerin detaylandırıldığı içerik metinlerinde sismik haraketliliğin ve tsunami verilerini paylaşan kurumların farklı bilgiler paylaşılması paylaşılmaktadır. Toplam 285 kelime ile aktarılan haber içeriklerinde afetlere yönelik toplumsal kapasite geliştirme ile ilgili anlamlı bir bütün oluşturabilecek herhangi bir ifade kullanılmamaktadır. Haberde deprem ve akabinde gerçekleşen tsunami olayının etki alanlarına ve neden olduğu hasarlara yönelik fotoğraflar ve harita ile ölen Türk vatandaşının fotoğrafı yayımlanmaktadır. Ayrıca 'kucağında bebek olan bir kadın' ve 'sokak kenarında oturan kadınlar' fotoğrafları kullanılarak bölgede yaşayanların artçı sarsıntılar nedeniyle evlerine girmedikleri aktarılmaktadır. Toplam 7 görselin bulunduğu haberde afetlere yönelik kapasite geliştirmeyi destekleyen herhangi bir görsel bulunmamaktadır. Habere ayrılan alan ve ana sayfa üzerindeki konumu değerlendirildiğinde ise gazete tarafından olayın haber değerinin yüksek algılandığı gözlemlenmektedir.

Hürriyet Gazetesi'nin 23 Temmuz tarihli baskısında habere ana sayfa alanının 11'de 1 oranından biraz fazla bir alan ayrılmakta ve haber Bodrum Belediye Başkanı'nın açıklamasına atıf yapılan bir başlık ile yayımlanmakta ve hayatın normale döndüğü açıklanmaya çalışılmaktadır. Hayatın normale döndüğü haberin başlık yazısında da tekrarlanmaktadır. 
Haber içerik metinlerinde Bodrum Belediye Başkanı'nın açıklamalarına yer verilmekte ve bölgede tatile devam edilebileceği belirtilmektedir. Haberde kullanılan fotoğrafta da bu durumu destekleyen denizde yüzen ve sahilde güneşlenen insanların fotoğrafı yayımlanmaktadır. Toplam 55 kelime ile aktarılan haber içeriklerinde afetlere yönelik toplumsal kapasite geliştirme ile ilgili anlamlı bir bütün oluşturabilecek herhangi bir ifade kullanılmamaktadır. Habere ayrılan alan ve ana sayfa üzerindeki konumu değerlendirildiğinde ise gazete tarafindan olaya verilen haber değerinin azaldığı gözlemlenmektedir. 21 Temmuz 2017 tarihinde meydana gelen deprem ve tsunami olaylarına ait herhangi bir haber veya içerik 24 Temmuz 2017 tarihinde yayınlanan Hürriyet Gazetesi ana sayfasında yer almamaktadır.

Tablo 4: 21, 22, 23 ve 24.07.2017 Tarihli Sözcü Gazeteleri ana sayfa haber incelemeleri

\begin{tabular}{|c|c|c|c|c|c|c|}
\hline \multirow{2}{*}{\multicolumn{3}{|c|}{$\frac{\text { Gazete Adı }}{\text { Yayın Tarihleri }}$}} & \multicolumn{4}{|c|}{ Sözcü Gazetesi (2017) } \\
\hline & & & $\begin{array}{c}21 . \\
7\end{array}$ & 22.7 & 23.7 & $\begin{array}{c}24 . \\
7\end{array}$ \\
\hline \multirow{7}{*}{ 竎 } & \multirow[b]{4}{*}{ 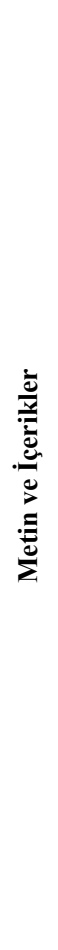 } & 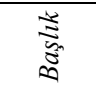 & \multirow{7}{*}{ 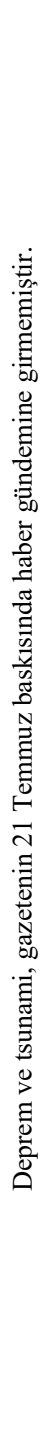 } & 6.6'lık depremde sağlam kaldı, böyle dedirtti: Bodrum Kale Gibi & Bodrum Palas & \multirow{7}{*}{ 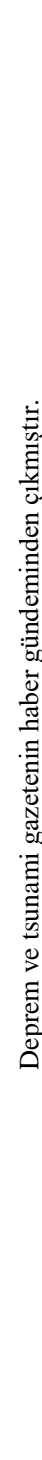 } \\
\hline & & 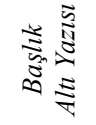 & & $\begin{array}{l}\text { Önce deprem vurdu, sonra tsunami dalgaları geldi. Buna rağmen Bodrum'da } \\
\text { can kaybı yaşanmadı. Binalarda ciddi hasarlar oluşmadı. }\end{array}$ & & \\
\hline & & 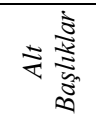 & & $\begin{array}{l}\text { Rahat Olun Faydaki Stres Boşaldı, Evlere Giremediler, Kandilli: Tsunami } \\
\text { Oldu, Bakan: Su Yükseldi, Daha Güvenli Yer Yok, Tatilin Tadını Çıkarın, } \\
\text { Kos'ta Ölen } 2 \text { Kişiden 1'i Türk. }\end{array}$ & ---- & \\
\hline & & 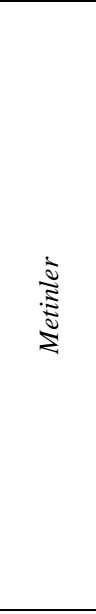 & & $\begin{array}{l}\text { Türkiye'de önceki gece deprem kâbusu vardı. Merkezi Ege'de Gökova } \\
\text { Körfezi olan deprem, İzmir'den Antalya'ya kadar her yerde hissedildi. } \\
\text { Depremin büyüklüğünü Kandilli } 6.6 \text { olarak duyurdu. AFAD ise önce } 6.6 \text { dedi } \\
\text { sonra 6.5'e indirdi. En büyük korku Bodrum'da yaşandı. Halk panikle sokağa } \\
\text { döküldü... Artçı sarsıntılar peş peşe sürerken, } 30 \text { - } 40 \text { santimlik tsunami } \\
\text { dalgaları karaya ulaştı. Arabaları sürükledi, tekneleri karaya vurdu. } \\
\text { Bodrum'da önemli bir yıkım yaşanmamış olması, ilçedeki binaların kale gibi } \\
\text { sağlam olduğunu gösterdi. Bodrumlular geceyi sokakta geçirdi. (Bilim } \\
\text { insanının adı soyadı haber kaynağında verilmektedir), "Bodrum rahat etsin. } \\
\text { Bu fay hattında stres boşaldı" dedi. Kandilli Rasathanesi'nin bilim insanları, } \\
\text { Ege Denizi'nde tsunami olduğunu açıkladı. Ancak Orman Bakanı Veysel } \\
\text { Eroğlu, "Tsunami olmadı. Deniz suyu } 10 \text { santim yükseldi" dedi. Tsunami } \\
\text { dalgaları tekneleri karaya vurdu. } 358 \text { kişi yaralandı. Hastalara dişarıda } \\
\text { müdahale edildi. Depremde masanın altına girdiler. Dalgalar sokaklardaki } \\
\text { otomobilleri sürükledi. Bodrum Belediye Başkanı Mehmet Kocadon, ilçeyi } \\
\text { sokak sokak gezdi. Korku içindeki vatandaşlara moral verdi. "Bodrum'dan } \\
\text { ayrılmayın" çağrısı yaptı. Deprem Yunanistan'ın İstanköy (Kos) Adası'nda } \\
\text { ağır hasara yol açtı. Bir caminin minaresi yıkıldı. Türk turist (adı soyadı } \\
\text { haber kaynağında verilmektedir) ve bir İsveçli enkaz altında can verdi. }\end{array}$ & $\begin{array}{c}\text { İki gün önce 6.6'lık depremle } \\
\text { sarsılan Bodrum'da artçı şoklar } \\
\text { halkı korkuttu. Binalarda } \\
\text { kalmak istemeyenler açık } \\
\text { havada sabahladı. Kimi } \\
\text { yatağını yol kenarına serdi, } \\
\text { kimi şezlongda uyudu. Ortaya } \\
\text { bu manzara çıktı. } \\
\text { Deniz manzaralı uyku keyfi... } \\
\text { Şezlongda uyku... } \\
\text { Kaldırımda uyku... }\end{array}$ & \\
\hline & \multirow[t]{3}{*}{ 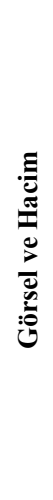 } & 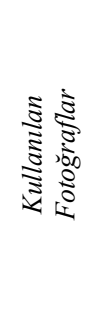 & & $\begin{array}{c}\text { Görsel-1: Açık alanda sedyede yatan yaralılar, sandalyede oturan insan ve } \\
\text { yanlarında ayakta bekleyen insanlar. } \\
\text { Görsel-2: Kaldırıma çıkmış araç ve etrafa saçılan çeşitli nesneler ve durumu } \\
\text { izleyen insanlar. } \\
\text { Görsel-3: Masa altına saklanan hastane personeli. } \\
\text { Görsel-4: Limanda hasar görmüş tekneler. } \\
\text { Görsel-5: Deprem ile ilgili açılklama yapan bilim insanının fotoğrafi. } \\
\text { Görsel-6: Ölen İsveç vatandaşının fotoğrafi. } \\
\text { Görsel-7: Ölen Türk vatandaşının fotoğrafi. }\end{array}$ & $\begin{array}{l}\text { Görsel -1: Arka fonda Bodrum } \\
\text { ve denizin olduğu kaldırımda } \\
\text { uyuyan insanlar. } \\
\text { Görsel -2: Açık alanda uyuyan } \\
\text { insanlar. } \\
\text { Görsel 3: Kaldırımda uyuyan } \\
\text { insanlar, yol kenarına park } \\
\text { etmiş araçlar ve uzaktan farları } \\
\text { yanan araç. }\end{array}$ & \\
\hline & & $\begin{array}{c}\text { Konum } \\
u\end{array}$ & & Sağ iki sütun hariç orta alan & Sol iki sütun hariç orta alan & \\
\hline & & $\begin{array}{l}\text { Ana } \\
\text { Sayfa } \\
\text { Alani }\end{array}$ & & $\begin{array}{l}32,4(\mathrm{~cm}) \times 52.5(\mathrm{~cm}) \\
=1.701\left(\mathrm{~cm}^{2}\right)\end{array}$ & $\begin{array}{l}32,4(\mathrm{~cm}) \times 52.5(\mathrm{~cm}) \\
=1.701\left(\mathrm{~cm}^{2}\right)\end{array}$ & \\
\hline
\end{tabular}


Tablo 4'ün devamı

\begin{tabular}{|c|c|c|c|}
\hline & $\begin{array}{l}\text { Haber } \\
\text { Alanı }\end{array}$ & $\begin{array}{c}22,3(\mathrm{~cm}) \times 26,4(\mathrm{~cm})+6,9(\mathrm{~cm}) \times 8,9(\mathrm{~cm}) \\
=650,13\left(\mathrm{~cm}^{2}\right)\end{array}$ & $\begin{array}{l}22,2(\mathrm{~cm}) \times 15,8(\mathrm{~cm}) \\
\quad=350,76\left(\mathrm{~cm}^{2}\right)\end{array}$ \\
\hline \multirow{2}{*}{ 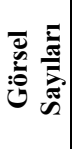 } & Toplam & 7 & 3 \\
\hline & $\begin{array}{l}\text { Afete } \\
\text { Hazirlık }\end{array}$ & 1 & 0 \\
\hline \multirow{2}{*}{ 离 } & Toplam & 224 & 39 \\
\hline & $\begin{array}{l}\text { Afete } \\
\text { Hazirllk }\end{array}$ & 4 & 0 \\
\hline
\end{tabular}

21 Temmuz 2017 tarihinde meydana gelen deprem ve tsunami olaylarının Sözcü Gazetesi’nin aynı tarihli baskısında yer almadığı görülmektedir. 22 Temmuz tarihli baskısında haber olarak yayımlanan deprem ve tsunami için gazetenin ana sayfasında 3 'te 1 oranından fazla bir alan ayrılmaktadır. Haber başlı̆gında Bodrum'da depremin yapısal hasara neden olmadığına atıfta bulunularak ilçede ki yapı stokunun sağlamlığı belirtilmeye çalışılmaktadır. Başlık altı açıklama yazısında ise deprem ve tsunami nedeniyle Bodrum'da can kaybı yaşanmaması vurgulanmakta ve yapısal sağlamlık tekrarlanmaktadır. Haberin alt başlıklarında ise sismik bir tehlikenin kalmadığ açıklamalarındaki kavramsal farklılıklar, normal yaşama devam edilmesi gerekliliği ve Kos Adası'ndaki ölümler ön plana çıkarılmaktadır. Haber içerisinde kullanılan metinlerde depremin hissedildiği bölgeler ve bölgede yaşayanlar üzerindeki etkisi ve ilgili kurumlarca yapılan açıklamalarda paylaşılan verilerin farklılıkları belirtilmektedir. Yine yapısal sağlamlığın tekrar edildiği içeriklerde uzman görüşüne yer verilerek bölgenin sismik olarak güvenli olduğu paylaşılmakta ve bazı sayısal ve durumsal veriler aktarılmaktadır.

Haber içeriğinde ayrıca Kos Adası'ndaki tarihi caminin minaresinin yıkılması sonucu ölen Türk vatandaşı ve İsveç vatandaşı bilgileri yer almaktadır. Haberde kullanılan toplam 224 kelime içerisinden 4'ü ile oluşturulan cümlede "Depremde masanın altına girdiler" afetlere yönelik toplumsal kapasite geliştirme kapsamında değerlendirilecek bir paylaşım yapılmaktadır. Ayrıca haberin farklı bölümlerinde kullanılan " 6.6 'lık depremde sağlam kaldı, böyle dedirtti: Bodrum Kale Gibi” ve "Bodrum'da önemli bir yıkım yaşanmamış olması, ilçedeki binaların kale gibi sağlam olduğunu gösterdi” ifadeleri deprem özelinde yapısal sağlamlığın önemini belirtmesine rağmen yapısal açıdan doğrudan bir bilgilendirme yapmamasından dolayı değerlendirme kapsamına alınmamıştır. Kullanılan haber görselleri deprem ve tsunami olaylarının neden olduğu hasar ve yaralanmaları, Bodrum'un güvenli olduğunu belirten uzman ve Belediye Başkanı fotoğrafları ile ölen Türk vatandaşının fotoğrafı yer almaktadır. Ayrıca gazete haber görselleri arasında deprem anında masa altında korunan bir hastane çalışanı fotoğrafina yer vermektedir. Bu bağlamda deprem anında nasıl korunabileceğini göstermesi bakımında 7 görsel ile birlikte servis edilen haberde afetlere yönelik kapasite geliştirmeyi destekleyen 1 adet görsel bulunmaktadır. Olayın gazete ana sayfası üzerinde kapladığı alan ve konumu değerlendirildiğinde olayın gazete tarafından haber değerinin yüksek olarak algılandı̆̆ı gözlemlenmektedir.

Haberi "Bodrum Palas" başlığı ile yayımlayan 23 Temmuz 2017 tarihli Sözcü Gazetesi ana sayfasında olaya toplam ana sayfa alanının 5 'te 1 oranından biraz fazla bir alanın ayrıldığı görülmektedir. Haber içerik metinlerinde artçı depremler nedeniyle bölge halkının evlerine girmedikleri ve sahil kenarında veya yol kenarında uyudukları aktarılmaktadır. Toplam 39 kelime ile aktarılan haberde afetlere karşı toplumsal kapasite geliştirme ile ilgili anlamlı bir bütün oluşturabilecek herhangi bir ifade kullanılmamaktadır. Haberde açık alanda uyuyan insanların olduğu fotoğraf kullanılarak bölge halkının tedirginliklerinin devam ettiği gösterilmektedir. Toplam 3 görselin bulunduğu haberde afetlere yönelik kapasite geliştirmeyi destekleyen herhangi bir görsel bulunmamaktadır. Habere ayrılan alan ve ana sayfa üzerindeki konumu değerlendirildiğinde ise gazete tarafından olaya verilen haber değerinin azaldığı gözlemlenmektedir. Gazetenin 24 Temmuz 2017 tarihli baskısında ise 21 Temmuz 2017 tarihinde meydana gelen deprem ve tsunami olaylarına ait herhangi bir haber veya içerik yer almamaktadır.

\subsection{Televizyon Haberleri}

Show TV, Fox TV ve ATV ana haber programında yayınlanan haberlerin; işitsel içerikleri (Haber Başlığı, Haber Spotları, Sunucunun Okuduğu Metinler, Videolarda Okunan Metinler), görsel içerikleri (Sunucunun Sunumunda Kullanılan Görsel Konseptler, Videolarda Kullanılan Görsel Konseptler), süre içerikleri (Konuya Ayrılan Süreler, Konuya Ayrılan Toplam Süre, Haber Programı Toplam Süresi ve Sunulan Toplam Haber Sayısı) ve kelime sayıları (toplam, afet hazırlık) verileri Tablo 5, Tablo 6 ve Tablo 7'desunulmaktadır (URL-4 2018). 
Tablo 5: 21.07.2017 Tarihli Show TV ana haber incelemeleri

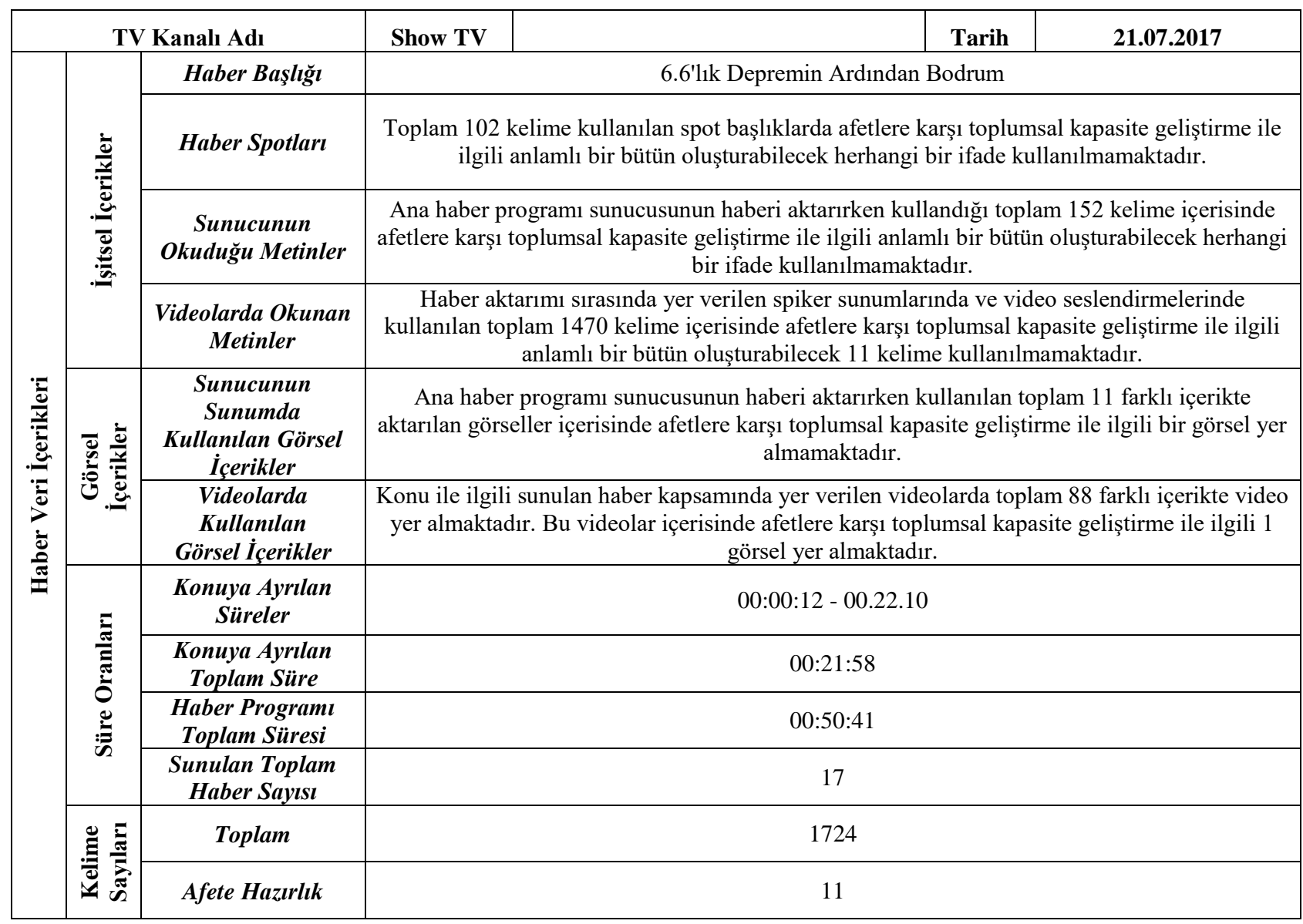

Deprem ve tsunami olaylarının meydana geldiği tarihte Show TV ana haber programında haber “6.6’lık Depremin Ardından Bodrum" başlığı ile aktarılmaktadır. 50 dakika 41 saniye süren ana haber programında toplam 17 haber aktarılırken 21 dakika 58 saniye ile en uzun süre bu habere ayrılmaktadır. Bu bağlamda program tarafından haber değerinin yüksek görüldüğü kabul edilmektedir. Program içerisinde olay haber olarak sunulurken haber spot başlıklarda 102 kelime, sunucunun okuduğu metinlerde 152 kelime, haber içerisinde yer verilen spiker konuşmaları ve video seslendirmelerinde ise 1470 kelime kullanılmaktadır. Toplam 1724 kelime ile gerçekleştirilen haber sunumunda 11 kelimenin kullanıldığı bir cümle ile (Masaların altına canlarını ve evlatlarını kurtarabileceklerini düşünenler sarsıntı bitince dışarı çıktı.) afetlere karşı toplumsal kapasite geliştirmeyi destekleyecek bütünlükte anlamlı bir ifade kullanılmaktadır.

Haber sunumunda kullanılan görseller değerlendirildiğinde ana haber programını sunucusunun yer aldığı zaman dilimlerinde 11, bölgeden yapılan spiker sunumlarında ve video içeriklerinde ise 88 farklı içerikte görüntüler aktarılmaktadır. Olayının Show TV ana haber programında haber olarak sunumu esnasında toplam 99 farklı içerikte görsel kullanılmakta ve bu görseller arasında 1 görselin (sarsıntı anında düşen nesnelere karşı masa altında korunma) afetlere karşı toplumsal kapasite geliştirmeyi kısmen destekleyecek nitelikte olduğu görülmektedir. Aktarılan görüntülerde masanın tavandan kopan parçalara karşı altında saklananı koruyacak sağlamlıkta olduğu görünmesine rağmen seslendirilen metinlerde bu vurgunun yapılmaması kapasite geliştirmeye yönelik sağladığı desteğin kısıtlı kalmasına neden olmaktadır. 
Tablo 6: 21.07.2017 Tarihli Fox TV ana haber incelemeleri

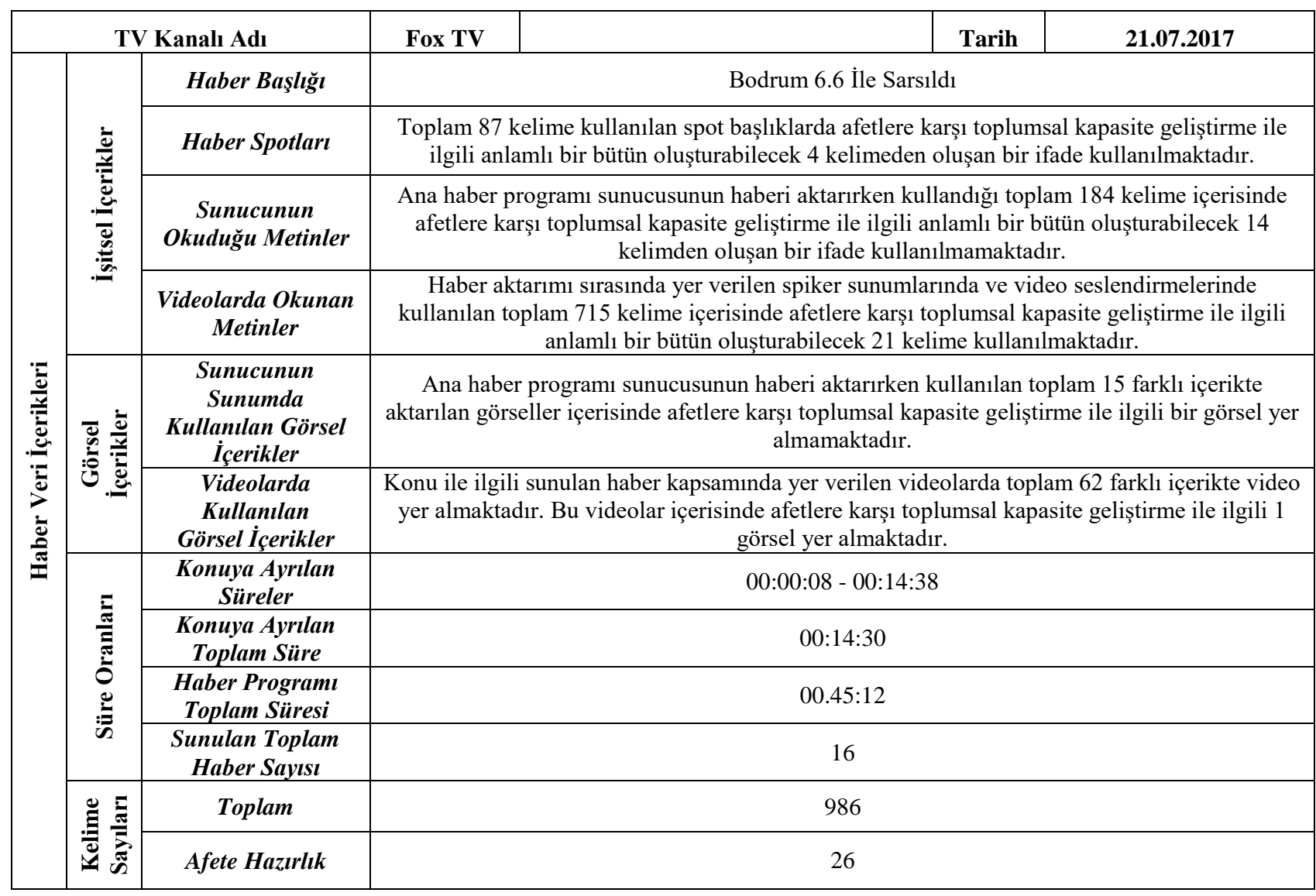

21 Temmuz 2017 tarihinde meydana gelen deprem ve tsunami olayları aynı tarihli Fox TV ana haber programı içerisinde "Bodrum 6.6 ile Sarsıldı" başlığı ile aktarılmaktadır. 45 dakika 12 saniye süren program dâhilinde toplam 16 haber aktarılırken haber bazında en uzun süre 14 dakika 30 saniye ile deprem ve tsunami olaylarına ayrılmaktadır. Bu bağlamda program tarafindan olayın haber değeri yüksek kabul edilmektedir. Haberin aktarımında ise spot başlıklarda 87 kelime, sunucunun okuduğu metinlerde 184 kelime, haber içerisinde yer verilen spiker konuşmaları ve video seslendirmelerinde ise 715 kelime kullanılmaktadır. Toplam 986 kelime ile gerçekleștirilen haber sunumunda afetlere karşı toplumsal kapasite geliştirmeyi destekleyecek bütünlükte 26 kelimenin kullanıldığı cümleler (Masa Altında Korunmaya Çalıștılar. Hastane çalışanları ve hasta yakınları kendilerini masa altına atarak korumaya çalıştı. ${ }^{l}$ )yer almaktadir.

Haber içerisinde uzman görüşüne dayandırılan "Marmara Bölgesi her an benzer bir depremle karşı karşıya kalabilir" söylemi deprem riski altındaki bir başka bölge için uyarı niteliği taşısa da afetler öncesinde yapılması gereken hazırlıklar kapsamında ve rol ve sorumluluklar bağlamında bir anlam ifade etmediği için değerlendirme kapsamına alınamamaktadır. Haber sunumunda kullanılan görseller değerlendirildiğinde ana haber programını sunucusunun yer aldığ zaman dilimlerinde 15, bölgeden yapılan spiker sunumlarında ve video içeriklerinde ise 62 farklı içerikte görüntüler aktarılmaktadır. Deprem ve akabinde gerçekleşen tsunami olayının Fox TV ana haber programında haber olarak sunumu esnasında toplam 77 farklı içerikte görsel kullanılmakta ve bu görseller arasında 2 görselin (sarsıntı anında düşen nesnelere karşı masa altında korunma) afetlere karşı toplumsal kapasite geliştirmeyi destekleyecek nitelikte olduğu görülmektedir.

\footnotetext{
1 "Hastane çalışanları ve hasta yakınları kendilerini masa altına atarak korumaya çalıştı" cümlesi haber içerisinde iki defa tekrar
} edilmektedir. Bu nedenle toplumsal kapasiteyi destekleyecek bütünlükte kullanılan kelime saylsı 26 olarak kabul edilmektedir. 
Tablo 7: 21.07.2017 Tarihli ATV ana haber incelemeleri

\begin{tabular}{|c|c|c|c|c|c|}
\hline \multicolumn{3}{|c|}{ TV Kanalı Adı } & ATV & Tarih & 21.07.2017 \\
\hline \multirow{12}{*}{ 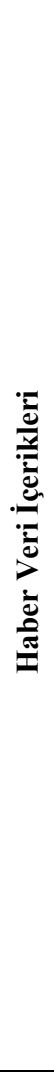 } & \multirow{4}{*}{ 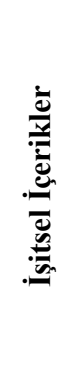 } & Haber Başlı̆̆ı & \multicolumn{3}{|c|}{ Günün Manşeti Deprem } \\
\hline & & Haber Spotları & \multicolumn{3}{|c|}{$\begin{array}{c}\text { Toplam } 213 \text { kelime kullanılan spot başlıklarda afetlere karşı toplumsal kapasite geliştirme ile } \\
\text { ilgili anlamlı bir bütün oluşturabilecek } 7 \text { kelime kullanılmaktadır. }\end{array}$} \\
\hline & & $\begin{array}{l}\text { Sunucunun } \\
\text { Okuduğu Metinler }\end{array}$ & \multicolumn{3}{|c|}{$\begin{array}{c}\text { Ana haber programı sunucusunun haberi aktarırken kullandığı toplam } 387 \text { kelime içerisinde } \\
\text { afetlere karşı toplumsal kapasite geliştirme ile ilgili anlamlı bir bütün oluşturabilecek } 12 \\
\text { kelime kullanılmaktadır. }\end{array}$} \\
\hline & & $\begin{array}{l}\text { Videolarda Okunan } \\
\text { Metinler }\end{array}$ & \multicolumn{3}{|c|}{$\begin{array}{l}\text { Haber aktarımı sırasında yer verilen spiker sunumlarında ve video seslendirmelerinde } \\
\text { kullanılan toplam } 1372 \text { kelime içerisinde afetlere karşı toplumsal kapasite geliştirme ile ilgili } \\
\text { anlamlı bir bütün oluşturabilecek } 12 \text { kelime kullanılmaktadır. }\end{array}$} \\
\hline & 离 & $\begin{array}{l}\text { Sunucunun } \\
\text { Sunumda } \\
\text { Kullanılan Görsel } \\
\text { İçerikler }\end{array}$ & \multicolumn{3}{|c|}{$\begin{array}{l}\text { Ana haber programı sunucusunun haberi aktarırken kullanılan toplam } 8 \text { farklı içerikte } \\
\text { aktarılan görseller içerisinde afetlere karşı toplumsal kapasite geliştirme ile ilgili bir görsel yer } \\
\text { almamaktadır. }\end{array}$} \\
\hline & ن. & $\begin{array}{c}\text { Videolarda } \\
\text { Kullanılan } \\
\text { Görsel İçerikler } \\
\end{array}$ & \multicolumn{3}{|c|}{$\begin{array}{c}\text { Konu ile ilgili sunulan haber kapsamında yer verilen videolarda toplam } 63 \text { farklı içerikte } \\
\text { video yer almaktadır. Bu videolar içerisinde afetlere karşı toplumsal kapasite geliştirme ile } \\
\text { ilgili } 1 \text { görsel yer almaktadır. }\end{array}$} \\
\hline & \multirow{4}{*}{ 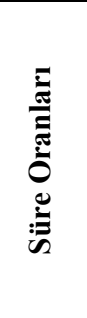 } & $\begin{array}{l}\text { Konuya Ayrilan } \\
\quad \text { Süreler }\end{array}$ & \multicolumn{3}{|c|}{$\begin{array}{c}\text { 00:00:00 - 00:02:25, 00:06:40 - 00:06:56, 00:29:18 - 00:29:26, 00:40:00 - 00:55:00, 00:55:15 } \\
-01: 06: 28\end{array}$} \\
\hline & & $\begin{array}{l}\text { Konuya Ayrılan } \\
\text { Toplam Süre }\end{array}$ & \multicolumn{3}{|c|}{ 00:29:02 } \\
\hline & & $\begin{array}{c}\text { Haber Programı } \\
\text { Toplam Süresi }\end{array}$ & \multicolumn{3}{|c|}{$01: 26: 20$} \\
\hline & & $\begin{array}{c}\text { Sunulan Toplam } \\
\text { Haber Sayıst }\end{array}$ & \multicolumn{3}{|c|}{32} \\
\hline & \multirow{2}{*}{ 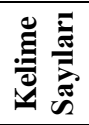 } & Toplam & \multicolumn{3}{|c|}{1972} \\
\hline & & Afete Hazırlık & \multicolumn{3}{|c|}{55} \\
\hline
\end{tabular}

ATV ana haber programında da deprem ve tsunaminin meydana geldiği tarihte olaya yer verilmekte ve haber "Günün Manşeti Deprem" başlığında aktarılmaktadır. 1 saat 26 dakika 20 saniye süren ana haber programında toplam 32 haberin aktarıldığı ve 29 dakika 2 saniye ile en uzun sürenin konuya ayrıldığı görülmektedir. ATV ana haber programında incelenen diğer ana haber programlarından farklı olarak olayın haberinin sunulduğu zaman dilimine kadar program içerisinde "az sonra" başlığında haberin duyurusu yapılmaktadır. Olayın haberine ayrılan süre bağlamında ATV ana haber programı tarafından da haber değerinin yüksek kabul edildiği görülmektedir.

Program dâhilinde olay haber olarak sunulurken spot başlıklarda 213 kelime, sunucunun okuduğu metinlerde 387 kelime, haber içerisinde yer verilen spiker konuşmaları ve video seslendirmelerinde ise 1372 kelime kullanılmaktadır. Toplam 1972 kelime ile gerçekleştirilen haber sunumunda 55 kelimenin kullanıldığ (Afetlere Hazırlıklı Olmalıyız, Alınan Tedbirler Hayat Kurtardı Dolayısıyla vatandaşlar da daha sakin ve daha soğukkanlı olmayı ögrendiler. Çünkü öyle olmakta fayda var. Uzmanlar artçı sarsıntıların normal olduğunu olması da gerektiğini, çünkü olmazsa yerin altındaki enerjinin açı̆̆a çıkmayacă̆ını daha büyük depremlere neden olabileceğini söylüyor, Afetlere karşı hazırlıklı olunmalı mesajı verdi ve Cumhurbaşkanı alınan tedbirlerin hayat kurtardığını söyledi) ifadelerinden oluşan cümleler afetlere karşı toplumsal kapasite geliştirmeyi destekleyecek bütünlükte bir anlam ifade etmektedir.

Haber sunumunda kullanılan görseller değerlendirildiğinde ise ana haber programını sunucusunun yer aldığı zaman dilimlerinde 8, bölgeden yapılan spiker sunumlarında ve video içeriklerinde ise 63 farklı içerikte görüntüler aktarılmaktadır. Olayının ATV ana haber programında haber olarak sunumu esnasında toplam 71 farklı içerikte görsel kullanılmakta ve bu görseller arasında 1 görselin (sarsıntı anında düşen nesnelere karşı masa altında korunma) afetlere karşı toplumsal kapasite geliştirmeyi destekleyecek nitelikte olduğu görülmektedir.

\section{Sonuç}

21 Temmuz 2017 tarihinde meydana gelen Akdeniz Gökova Körfezi sismik hareketliliği ve bu hareketlilik neticesinde özellikle Muğla'nın Bodrum ilçesinde yaşanan tsunami olaylarının 'haber çerçeveleme kuramı' ile incelenerek 'afetlere karşı toplumsal kapasite geliştirme' bağlamında etkileri değerlendirildiği bu çalışma ile aşağıdaki sonuçlara ulaşılmaktadır.

Haberler içerisinde deprem ve tsunami olaylarına yönelik aktarılan karakteristik verilerde farklı kurumların söz sahibi olduğu ve bu kurumların farklı veriler sunduğu, veri kaynaklarının "tsunami - su yükseldi” gibi farklı kavramlar kullandığı, gazete ve televizyon haberlerinde bu veriler aktarılırken bir standardın olmadığ 1 ve bunlarla beraber bazı haber 
sağlayıcılarının olaya yönelik kaynağı belli olmayan "1.5 metrelik dalga" gibi veriler sunduğu görülmektedir. Yine yayınlanan haber içeriklerinde " $A F A D$, Kandilli farkı" gibi ifadeler kullanılırken AFAD yetkililerince yapılan bir açıklama ve AFAD yetkililerinden bilgi alınma girişimine yönelik bir söylem yer almamaktadır. Oysa 27261 sayılı Resmi Gazete'de yayınlanan 5902 sayılı “Afet ve Acil Durum Yönetimi Başkanlığının Teşkilat ve Görevleri Hakkında Kanun”a göre ise afetler hakkında kamuoyunu bilgilendirme görevi Afet Acil Durum Başkanlığı'na (AFAD) verilmektedir (URL7 2018). Afetler gibi toplumun genelini ilgilendiren ve ilgili kanunlarla sorumluluk verilen resmi kurumların bu tarz haberlerde tek bilgi kaynağı olarak kullanılması kamuoyunda oluşabilecek bilgi kirliliğini engellemektedir, ancak sunulan haberlerin bu yaklaşımda olmadıkları görülmektedir.

Afetlere yönelik toplumsal hazırlık çalışmalarına yönelik geliştirilen bilimsel yöntemlerde çaresizlik ve korkuya neden olacak söylemler yerine yeterlilik/yapabilirlik algısını oluşturacak söylemlerin benimsenmesinin gerekliliği belirtilmektedir (Fişek vd. 2003). Ancak incelenen gazete ve televizyon haber içeriklerinde kullanılan başlık ve metinlerde “deprem Kos Adası'nı yıkarken”, "en büyük yıkım”, "birçok tekneyi karaya savurdu”, "yürekleri ağza getiren sarsıntı" gibi ifadeler olayın büyük ilgi çeken boyutu ile aktarıldığı ve yeterlilik/yapabilirlik algısına yönelik söylem geliştirme yaklaşımından uzak olduğunu göstermektedir. Yine toplumsal kapasite gelişiminde kitle iletişim araçlarından yararlanabilmek için yapılan bilimsel araştırmalarda afetler konusunu ilgilendiren uzmanlıklar tarafından yazılan bilgilendirici içeriklere medyada yer verilmesi önerilmektedir (Koç 2013). Ancak incelenen haber içeriklerinde "şiddet" ve "büyüklük" kavramlarının karıştı̆ı gözlemlenmesi ise konu hakkında basında yer alacak uzman görüşlerine, basın mensuplarının da afetler konusunda bilgilendirilmesi önerisinin eklenmesi ihtiyacını doğurmaktadır.

İnceleme süresince üç gazetenin deprem ve tsunami olaylarına yönelik ana sayfalarında sundukları tüm haberlerin toplam 918 kelimeden oluşan bir içerikle aktarıldığı ancak bu kelime sayıları içerisinde sadece 8 tanesinin afetlere yönelik toplumsal kapasite geliştirmeyi destekleyecek içerikte olduğu görülmektedir. Afetler açısından kırılgan bir ülke olduğu bilinen Türkiye'de günlük tirajları toplamı 910 bin 984 olarak bildirilen ve her gün yaklaşık 1 milyon insana doğrudan ulaşan en çok satan 3 gazetenin afetlerle ilgili haber içeriklerinde toplumsal kapasite geliştirmeye $\% 0,8$ yani $\% 1$ 'den daha az yer vermektedir. İnceleme kapsamındaki ana haber programlarında ise deprem ve tsunami haberlerine toplamda 74 dakika 30 saniye ayırılmakta ve bu süre zarfında haberin aktarımında 4 bin 682 kelime kullanılmaktadır. Ancak bu kelimeler içerisinde sadece 88 tanesinin afetlere yönelik toplumsal kapasite geliştirmeyi destekleyecek içerikte olduğu görülmektedir. Yani haber sunumlarında toplumsal kapasite geliştirmeye \%1.9 oranında yer verilmektedir. Yine ana haber programları dâhilinde deprem ve tsunami olayları 3 programda toplam 247 farklı görsel eşliğinde sunulmakta ancak bu görseller içerisinde sadece 4 tanesinin afetlere yönelik toplumsal kapasiteyi geliştirmeyi destekleyecek nitelikte olduğu gözlemlenmektedir. Bu durum oransal olarak ifade edildiğinde ise \%1.6'ya denk gelmektedir. Daha önce kitle iletişim araçlarının afetlerdeki işlevine yönelik yapılan bilimsel çalışmalarda toplumun afetler konusunda bilgilendirilmesi ve bilinçlendirilmesinde medyanın önemli rol aldığı belirtilmektedir (Soydan ve Alpaslan 2014). Ancak araştırma kapsamında incelenen kitle iletişim araçları üzerinde sunulan haberlerin medyaya atfedilen bu sorumluluğu sağlayabilecek niteliklerde olmadığını göstermektedir.

Yakın tarihte Türkiye'de gerçekleşen ve Bodrum Depremi'ne kıyasla çok daha büyük kayıplara neden olan 7.4 (Mw) büyüklüğündeki 17 Ağustos 1999 Gölcük Depremi ya da 23 Ekim 2011 tarihinde gerçekleşen 7.0 (Mw) büyüklüğündeki Van Depremi ile ilgili haberler incelendiğinde habere ayrılan alan ve zamanda can ve mal kayıplarının etkili olduğu belirtilmektedir (URL-8 2018; URL-9 2018; Koç 2013). Ancak Bodrum Depremi olarak medya gündemini meşgul eden olayın büyüklüğü ve neden olduğu kayıpların Gölcük ve Van Depremlerine kıyasla daha küçük kalmasına rağmen yüksek haber değeri ile sunulması Türkiye'deki basın araçlarının afet haberlerine önem verildiğini göstermektedir. Türkiye'de afet haberlerine önem verilmesine rağmen gerçekleştirilen bu araştırma ile haber içeriklerinde toplumsal yararı sağlayan afetlere karşı toplumsal kapasite geliştirmeye çok az önem verildiği sonucuna ulaşılmaktadır.

\section{Kaynaklar}

Akalın Ş.H., (2011), Türkçe Sözlük, Türk Dil Kurumu Yayınları, Ankara, Türkiye, 2673ss

Aslan K., (2002), Haberin Yol Haritası, İstanbul, Anahtar Yayınevi, 211ss.

Atabek N., Uztuğ F., (1998), Haberlerde çerçeveleme ve öne çıkarma, Kurgu Anadolu Üniversitesi İletişim Bilimleri Fakültesi Uluslararası Hakemli İletișim Dergisi, 15(1), 96-105.

Ayverdi İ., (2010), Misalli Büyük Türkçe Sözlük, Kubbealtı Yayınları, İstanbul, Türkiye, 1411ss.

Brinkerhoff D.W., Morgan P.J., (2010), Capacity and capacity development: Coping with complexity, Public Administration and Development, 30, 2-10.

Durur E.K., (2011), İnsancı yaklaşım içinde çerçeveleme kuramı ve haberin çerçevelenişi, Atatürk İletişim Dergisi, 2, 21-31.

Ekşi A., (2015), Afet yönetiminde içsel denetim aracı olarak etik, Uluslararası İktisadi ve İdari İncelemeler Dergisi, 8, 89-102.

Erdoğan İ., (2011), Gündem koyma ve saptama yaklaşımında bir araştırma geleneği ve tasarımı olarak çerçeveleme, Erciyes İletişim Dergisi, 2(1), 48-62.

Fişek G.O., Müderrisoğlu S., Yeniçeri N., Edinçliler A., Özkarar G., (2003), Deprem Zararlarının Azaltılması İçin Eğitim ve Sosyal Çalışmalar, Deprem Master Planı, İstanbul Büyükşehir Belediyesi Planlama ve İmar Dairesi Zemin ve Deprem İnceleme Müdürlüğü, İstanbul, Türkiye.

Haberl H., Fischer-Kowalski M., Krausmann F., Martinez-Alier J., Winiwarte V., (2011), A socio-metabolic transition towards sustainability? Challenges for another great transformation, Journal of Sustainable Development, 19, 1-14.

İnceoğlu M., (2004), Tutum Algı İletişim, Elips Kitap, Ankara, Türkiye, 248ss. 
İrvan S., Ragıp D., İlkiz F., (2005), Medya Etik ve Hukuk, IPS İletişim Vakfı Yayınları, İstanbul, Türkiye, 226ss.

Kadıŏlu M., (2008), Afet Zararlarını Azaltmanın Temel Illkeleri, JICA Türkiye Ofisi Yayınları No: 2, Ankara, Türkiye, 1-34.

Kadığlu M., (2011), Afet Yönetimi Beklenilmeyeni Beklemek En Kötüsünü Yönetmek, T.C. Marmara Belediyeler Birliği Yayını, İstanbul, Türkiye, 219ss.

Karancı N., Ural D., (2003), Afet Yönetimi ve Halk Ĕ̌itimi İstanbul İçin, Deprem Master Planı, İstanbul Büyükşehir Belediyesi Planlama ve İmar Dairesi Zemin ve Deprem İnceleme Müdürlügü, İstanbul, Türkiye.

Koç H., (2013), Türk basınının doğal afetlere ilişkin bakış açısını belirlemeye yönelik bir inceleme, Zeıtschrıftfürdie Welt der Türken / Journal of World of Turks, 136, 121-137.

Lavergne R., Saxby S., (2001), Capacity Development: Vision and Implications, Canadian International Development Agency, Capacity Development Occasional Series, Quebec, Canada. https://pdfs.semanticscholar.org/f691/ 05a3a85725ba3810352d9a4b 6275acdde167.pdf [Erişim Tarihi: 17 Mart 2018].

OECD, (2006), The Challenge of Capacity Development Working Towards Good Practice, Paris: DAC Guideline sand Reference Series-ADAC Reference Document, Paris, France. http://www.fao.org/fileadmin/templates/capacitybuilding/pdf/DAC_paper_ final.pdf, [Erişim 15 Mart 2018].

Otoo S., Agapitova N., Behrens J., (2009), The Capacity Development Results Framework A Strategic and Results-Oriented Approach to Learning for Capacity Development, Washington, DC: World Bank Institute Learning for Development, Washington, DC, USA. https://openknowledge.worldbank.org/bitstream/handle/10986/23037/The0capacity0d0capacity0development.pdf?sequence=1\&i sAllowed=y [Erișim 15 Mart 2018].

Özarslan H., (2007), Çerçeveleme Yaklaşımı Açısından Haber Çerçevelerinin İzler Kitle Düşünceleri Üzerindeki Etkisi, Doktora Tezi, T.C. Konya Selçuk Üniversitesi Sosyal Bilimler Enstitüsü, Halkla İlişkiler ve Tanıtım Anabilim Dalı, Araştırma Yöntemleri Bilim Dalı, Konya, Türkiye.

Özarslan H., Güran M.S., (2015), İletişim araştırmalarında çerçeveleme paradigması: son döneme ait bir inceleme, Selçuk İletişim Dergisi, 8(4), 32-48.

Özarslan H., Güran M.S., (2018), Çerçeveleme teorisinin halkla ilişkilerde kullanımı, Türkiyat Araştırmaları Dergisi, 34, $299-314$.

Özdikmen T., (2014), Afet ve Acil Durum Yönetimi Saha Uygulamalı Afet Yönetimi ve Acil Durum Metodolojileri, Seçkin Yayıncılık, Ankara, Türkiye, 310ss.

Özer K., (2000), Illetişimsizlik Becerisi, Sistem Yayıncılık, İzmir, Türkiye, 190ss.

Parsa S., (1993), Televizyon Haberciliği ve Kuramları, Ege Üniversitesi İletişim Fakültesi Yayınları, İzmir, Türkiye, 154ss.

Rigel N., (2000), Illeti Tasarımında Haber, Der Yayınları, İstanbul, Türkiye, 256ss.

Schlapp H., (2002), Gazeteciliğe Giriş, (çev. Işık Aygün), Vestfalya Eyaletler Yayımevi, İstanbul, Türkiye, 216ss.

Seyidov İ., (2014), Türk basınında sunulan kırım kriz haberlerinin çerçeveleme kuramı bağlamında incelenmesi, Akdeniz Üniversitesi İletişim Dergisi, 22, 60-73.

Soydan E., Alpaslan N., (2014), Medyanın doğal afetlerdeki işlevi, İstanbul Journal of Social Sciences, 62, 53-64.

Süslü B., (2013), Toplumsal Algının Şekillendirilmesi Sürecinde Medyanın Ahlaki Panik Üretiminin Örnek Olaylarla İncelenmesi, Yüksek Lisans Tezi, T.C. Ege Üniversitesi Sosyal Bilimler Enstitüsü, Genel Gazetecilik Anabilim Dalı, İzmir, Türkiye.

Toköz O., (1981), Temel Gazetecilik, Ankara Üniversitesi Siyasal Bilgiler Fakültesi Yayınları, Ankara, Türkiye, 160ss.

Toruk İ., (2008), Gutenberg'den Dijital Çağa Gazetecilik, Litera Türk Academia Yayınevi, İstanbul, Türkiye, 471ss.

Ural D., (2014), Acil Durum Hazırlık Kapasitesinin Artırılması, T.C. İstanbul Valiliği İstanbul Proje Koordinasyon Birimi İSMEP Yayınları, İstanbul, Türkiye, 78ss.

URL-1, (2017), https://www.etymonline.com, [Erişim Tarihi: 17 Mart 2017].

URL-2, (2018), http://www.koeri.boun.edu.tr/sismo/2/wp-content/uploads/2017/07/Gokova.Korfezi.v3.pdf, [Erișim 14 Mart 2018].

URL-3, (2018), http://www.medyatava.com, [Erişim 20 Mart 2018].

URL-4, (2018), http://www.showtv.com.tr, [Erişim 22 Mart 2018].

URL-5, (2018), https://www.fox.com.tr, [Erişim 22 Mart 2018].

URL-6, (2048), https://www.atv.com.tr,[Erişim 22 Mart 2018].

URL-7, (2018), Afet ve Acil Durum Yönetimi Başkanlığının Teşkilat ve Görevleri Hakkında Kanun, Resmi Gazete, Sayı: 27261, http://www.resmigazete.gov.tr/eskiler/2009/06/20090617-1.htm, [Erişim 6 Kasım 2018].

URL-8, (2018), http://www.koeri.boun.edu.tr/depremmuh/eqspecials/kocaeli/kocaeli_eq.htm, [Erișim 6 Kasım 2018].

URL-9, (2018), https://www.afad.gov.tr/tr/2385/Van-Depremi-Hakkinda, [Erişim 6 Kasım 2018].

Worldwatch Enstitüsü, (2016), Dünyanın Durumu 2016 Bir Kent Sürdürülebilir Olabilir Mi?, Çeviri: Duygu Kutluay, Türkiye İş Bankası Kültür Yayınları, İstanbul, Türkiye, 482ss. 